\title{
The American Racial Divide in Fear of the Police*
}

\author{
Forthcoming in Criminology \\ Justin T. Pickett \\ University at Albany, SUNY \\ Amanda Graham \\ Georgia Southern University \\ Francis T. Cullen \\ University of Cincinnati
}

\begin{abstract}
:
The mission of policing is "to protect and serve," but recent events suggest that many Americans, and especially Black Americans, do not feel protected from the police. Understanding police-related fear is important because it may impact civilians' health, daily lives, and policy attitudes. To examine the prevalence, sources, and consequences of both personal and altruistic fear of the police, we surveyed a nationwide sample $(\mathrm{N}=1,150)$, which included comparable numbers of Black $(\mathrm{N}=517)$ and White $(\mathrm{N}=492)$ respondents. Most White respondents felt safe, but most Black respondents lived in fear of the police killing them and hurting their family members. About half of Black respondents preferred to be robbed or burglarized than to have unprovoked contact with officers. The racial divide in fear was mediated by past experiences with police mistreatment. In turn, fear mediated the effects of race and past mistreatment on support for police defunding and intentions to have "the talk" with family youths about the need to distrust and avoid officers. The deep American racial divide in police-related fear represents a racially disparate health crisis and a primary obstacle to law enforcement's capacity to serve all communities equitably.
\end{abstract}

Keywords: Race, policing, emotions, Black Lives Matter, legal socialization 
How afraid a citizenry is of those policing it tells us a great deal about a society. No one in a just society would need to be fearful of being mistreated by the police. Widespread fear portends abuse of legal authority, much as disparities in fear across citizens by race speak loudly to the amount of racial injustice in their midst. Fear of police mistreatment is disconcerting for another reason. A voluminous literature on a closely related social problem, the fear of crime, shows that being afraid for oneself and especially for others — what is known as "altruistic fear"-profoundly affects people's daily lives (Drakulich, 2015; Warr \& Ellison, 2000). Being

personally or altruistically afraid of state representatives who are armed with lethal weapons and empowered with unparalleled discretion could only be more consequential (Fader, 2021; Lee \& Robinson, 2019; Stuart, 2016).

In the United States, the potential for unjust policing to foster fear is enormous. Each year, more than 50 million Americans have contacts with the police, about half of which are officer-initiated (Harrell \& Davis, 2020), and millions more experience contacts vicariously. The signs are growing that many Americans, particularly Black Americans, are living in fear of the police (Graham et al., 2020a), not only for themselves but also for others, such as their family members and friends. Calls to defund or disband the police suggest fear is prevalent. The emergence of the Black Lives Matter movement also suggests it, as do the unprecedented protests that erupted across the country after George Floyd Jr.'s killing beneath the knees of police. That police violence harms not only those directly involved, but also those living nearby suggests it as well—fear is one mechanism that would produce vicarious effects (Ang, 2021).

Unlike with the fear of crime, which has been studied for decades (Farrall et al., 2009; Lane et al., 2014), the evidence on the prevalence, sources, and consequences of police-related fear remains thin (Graham et al., 2020a). Consequently, several critical questions about police- 
related fear remain unanswered. Are personal and altruistic fear of the police widespread in the United States, or are they only prevalent among Black Americans? Because police are more likely to disrespect Black than White Americans (Voigt et al., 2017; Weitzer \& Tuch, 2006), and because Black Americans have a much higher lifetime risk of being killed by the police (Edwards et al., 2019), a racial gap in police-related fear is likely, but how large is it? Does past experience with police mistreatment mediate the racial gap in fear? Or, does fear mostly reflect exposure to news coverage, which increasingly has focused on police brutality in recent years (Ouss \& Rappaport, 2020)? What consequences does police-related fear have for Americans' policy attitudes and social lives? How frightening are specific types of police contact to members of the public?

To answer each of the abovementioned questions, we developed multiple-item measures of both personal and altruistic fear of police. We included them in a survey administered in early 2021 to a large national sample $(\mathrm{N}=1,150)$, which included comparable numbers of Black $(\mathrm{N}=$ 517) and White $(\mathrm{N}=492)$ respondents. Our survey also measured several theoretical sources of police-related fear, including past police mistreatment, overall news exposure, and neighborhood context, and it included measures of the likely consequences of fear-specifically, support for defunding the police and defensive legal socialization (i.e., having "the talk" with family members about the need to distrust and avoid officers). Not least, the survey included an experimental contingent valuation procedure, Rawlsian cost-benefit analysis (Stevenson \& Mayson, 2021), designed to assess the extent to which members of the public are frightened by the prospect of having specific types of contact with the police. Before describing our methods and findings, we first discuss the importance of studying police-related fear and review existing 
theoretical and empirical scholarship that provides insights about the likely sources and consequences of personal and altruistic fear of the police.

\section{WHY POLICE-RELATED FEAR IS IMPORTANT}

Prior studies of policing attitudes found both a racial divide - with Black Americans having the most negative attitudes and White Americans having the most positive—and a racial gradient — with other racial/ethnic minorities falling in between (Hagan et al., 2005; Reisig \& Parks, 2000; Weitzer \& Tuch, 2006). ${ }^{1}$ The size of the racial divide in policing attitudes varied tremendously, however, depending on the specific question asked (Roberts \& Stalans, 1997), and it was reduced or even eliminated once controls for neighborhood conditions were included ( $\mathrm{Wu}$ et al., 2009). Unfortunately, past research focused on perceptions and attitudes, such as satisfaction with police, perceived police effectiveness, and beliefs about police trustworthiness and legitimacy. It mostly overlooked fear of the police (Graham et al., 2020a).

Studying police-related fear is important for many reasons (Katz, 1988; Sherman, 2003). One is that it is at the heart of the United States' current police legitimacy crisis, and is the focal point of contemporary discussions about race and policing. Altruistic fear of the police, for example, appears to explain why many people risked their own lives to attend Black Lives Matter protests during the COVID-19 pandemic — as one protester put it, "if we don't put our bodies on the line, then our children will still be vulnerable to this kind of abuse" (Cobbina et al., 2021, p. 1213). Similarly, as Table 1 shows, it is the language of fear that has dominated public discourse about police-civilian relations in recent years, with prominent figures such as Michelle Obama, LeBron James, Senator Tim Scott, and Pulitzer Prize-winning columnist Eugene Harold

\footnotetext{
${ }^{1}$ Theoretically, the racial gradient reflects Black Americans' longer, more severe history with racial discrimination in the U.S. and the effects of having darker skin color in contemporary American society (Hagan et al., 2005).
} 
Robinson emphasizing that American policing fosters fear and anxiety even among law-abiding civilians, especially among law-abiding Black civilians.

\section{[Insert Table 1 about here]}

One recent photography series, Jon Henry's “Stranger Fruit," makes this clear. Through pictures of mothers holding their seemingly lifeless sons, it illustrates how police-related fear “permeates the daily lives of Black families across the United States” (Hornsby, 2021, p. 1). Indeed, some Black civilians indicate that fear of the police is their "number one fear in life" (Lee \& Robinson, 2019, p. 156) and that it imprisons them in their houses, limits their social interactions, and "effectively erases [them] from the public sphere" (Fader, 2021, p. 293). Stuart (2016, p. 300), for example, explained how police-related fear caused one individual to forfeit a job opportunity. When the prospective employee could not find the building where the job was located, "his fear of being misrecognized by the police" caused him to be too "fearful to ask nearby pedestrians for information or help.”

Another reason that studying police-related fear is important is that research has shown that cognitive judgments are different than emotions (Lane et al., 2014; Warr, 2000). Indeed, one of the main lessons from studies of fearfulness in other domains is that fear is not perceived risk, nor is it concern about a threat, nor an evaluation of its prevalence, severity, or controllability (Ferraro, 1995; Jackson, 2011; Roche et al., 2020). Rather, "fear is an emotion, a feeling of alarm or dread" (Warr, 2000, p. 453), and it has a direct and powerful effect on policy attitudes, on decision-making, and on behavior (Lane et al., 2014; Pickett et al., 2018a; Roche et al., 2020). The theoretical and empirical distinction between cognitions and emotions is as clear in the context of policing as it is in other areas (Barkworth \& Murphy, 2015; Schuck et al., 2008). Perceiving that the police are ineffective or illegitimate is fundamentally different than being 
afraid that they will hurt or kill you. To illustrate, it was not perceived police ineffectiveness or illegitimacy that kept Army Second Lieutenant Caron Nazario in his car during a traffic stop; it was fear: "I'm honestly afraid to get out," he told officers, to which they responded, "yeah, you should be!" (Foreman, 2021). Therefore, just as analyzing officers' emotions is important for understanding and improving police-civilian relations (Nix et al., 2019), it is critical to consider civilians' emotions, too (Barkworth \& Murphy, 2015; Katz, 1988). Indeed, as Sherman (2003, p. 2) emphasized, recognizing and managing the effects of emotions on the decision-making of both officers and civilians is necessary for developing an "emotionally intelligent" justice system.

Additionally, we know that students do worse in school after exposure to aggressive policing or police violence (Ang, 2021; Gottlieb \& Wilson, 2019; Legewie \& Fagan, 2019). We also know that suffering police mistreatment predicts later suicide ideation and attempts (Dennison \& Finkeldey, 2021; DeVylder et al., 2017a). Indeed, even experiencing routine enforcement practices, such as stops and searches, appears to increase future depression and psychological distress (Alang et al., 2021; Del Toro et al., 2019; DeVyler et al., 2017b). Lewis and $\mathrm{Wu}(2021, \mathrm{p} .1)$, for example, found that "being stopped by the police poses a greater risk to ... students' development of PTSD than living in a violent community." All these findings suggest that many Americans find various types of interactions with police to be traumatic, that they are afraid of those interactions occurring, and that this fear is a significant factor in their lives. What we still do not know, however, is how many Americans are afraid of the police, how fearful they are, whether their fear is for themselves or for others they care about, why they are afraid, or what consequences fear has for their social lives or views about the role of policing in society. Our study provides evidence on all of these fronts. 


\section{POLICE-RELATED FEAR: THEORETICAL SOURCES AND CONSEQUENCES}

The literature on victimization fear provides four theoretical models that are likely to be useful for understanding the sources of police-related fear: vulnerability, victimization, media cultivation, and neighborhood context (Farrall et al., 2009; Hale, 1996; Lane et al., 2014). The vulnerability model indicates that groups who believe they are exposed to danger, unable to protect themselves, and susceptible to serious consequences should be more fearful. In the case of fear of crime, this means that women, the elderly, and racial/ethnic minorities should be more afraid (Hale, 1996). In the context of policing, given objective exposure patterns (Edwards et al., 2019) and Black Americans' "shared historical memories of police malfeasance" (McCarthy et al., 2020, p. 510), the vulnerability model indicates that a direct relationship should exist between race and fear of the police, with Black Americans being the most afraid. In Kaba's (2020, p. 1) words, "there is not a single era in the United States history in which the police were not a force of violence against Black people.” As Hagan et al. (2005, p. 384) explained, other racial/ethnic minorities, such as Hispanic Americans, occupied "a disadvantaged middle ground where they [were] a less comprehensive and intensive focus of criminalization efforts than African Americans, but more at risk than whites."

The vulnerability model also points to the importance of "perceptually contemporaneous" offenses, whereby individuals become frightened even of minor crimes because they view them "as a prelude to other more serious offences" (Warr, 1984, p. 695). Extended to the policing context, this means that even minor forms of police contact, such as stops or searches, may frighten Black Americans, who may view them as a prelude to serious police violence. This is especially likely given the unpredictability of officer behavior in police stops (Fader, 2021). For example, Weaver et al. (2019, p. 112) found that law-abidingness has provided less insurance 
against arrest in recent decades, particularly for Black Americans, a finding they termed "the great decoupling." Consequently, given the uncertainty about how officers will behave, there may be a "shadow of wrongful arrest" or "shadow of police brutality" surrounding all policecivilian interactions for Black Americans, just as there is a "shadow of sexual assault" surrounding all forms of face-to-face crime for women (Ferraro, 1996, p. 667).

The second model, the victimization model, is straightforward. People with past personal or vicarious victimization experience should be more afraid (Farrall et al., 2009; Lane et al., 2014). Vicarious experience may be especially frightening because "it allows one's imagination full scope without perhaps the same urgency to find some coping strategy" (Hale, 1996, p. 105). In the policing context, this means that past personal or vicarious experience with police mistreatment should increase fear (Schuck et al., 2008). Compared to other racial/ethnic groups, Black Americans report the most personal and vicarious experience with police mistreatment (Dennison \& Finkeldey, 2021; Rosenbaum et al., 2005; Weitzer \& Tuch, 2006). For example, $71 \%$ of Black Americans know someone who was treated unfairly by police, compared to only 48\% of Hispanic Americans, 51\% of Asian Americans, and 34\% of White Americans (Momolu, 2020). By extension, the victimization model indicates that an indirect relationship should exist between race and fear of the police via experienced mistreatment. It also indicates that a racial gradient in fear should exist, with Black Americans being the most afraid, White Americans the least afraid, and other racial/ethnic minorities (e.g., Hispanic and Asian Americans) falling in between these extremes.

Whereas the victimization model indicates that fear reflects lived reality, the media cultivation model does not (Hale, 1996; Lane et al., 2014). Instead, it indicates that exposure to news coverage, which bears little relation to reality and focuses on the most extreme or 
newsworthy events, leads viewers to become more fearful (Baranauskas \& Drakulich. 2018;

Chiricos et al., 2000; Roche et al., 2016; Simmons, 2017). In other words, news exposure "cultivates the view among audience members that the real world mirrors that of media accounts," even though it rarely does (Roche et al., 2016, p. 216). Some evidence exists that news exposure is associated with policing attitudes (Callanan \& Rosenberger, 2011; Weitzer \& Tuch, 2006). We also know that news stories about police violence have increased tremendously in recent years, a trend that bears little resemblance to that for police behavior (Ouss \& Rappaport, 2020). ${ }^{2}$ The media cultivation model thus suggests the possibility that police-related fear may be a social construction - a phenomenon real in its consequences, but weakly tethered to reality.

Finally, the neighborhood context model indicates that whether people are afraid depends on what they encounter on a regular basis in their immediate surroundings (Farrall et al., 2009; Hale, 1996). In the context of crime, neighborhood disorder, racial heterogeneity, and police presence, which all may be perceived as signs of danger, should increase fear, whereas collective efficacy should reduce it, both by reducing crime and by fostering interpersonal trust (BruntonSmith \& Patrick Sturgis, 2011; Drakulich, 2013; Gibson et al., 2002; Hinkle \& Weisburd, 2008). Although the underlying mechanisms differ, these same factors appear to affect attitudes toward the police (Drakulich \& Crutchfield, 2013; Nix et al., 2015; Pickett et al., 2018b) and to help explain the attitudinal racial divide (Sun et al., 2009). In the context of policing, disorder and collective efficacy may speak to the moral standing of the police (Jackson \& Bradford, 2009), an important sign of "police danger" may be the regular presence of officers in one's neighborhood, and a cue to neighbors' vulnerability to mistreatment may be their racial composition.

\footnotetext{
${ }^{2}$ Ouss \& Rappaport (2020) used liability insurance claims to evaluate trends in police misbehavior between 1992 and 2018 , and found that misbehavior likely declined.
} 
Additionally, having more Black neighbors may lead people to believe their neighborhood will be targeted for aggressive policing. Each of these factors, then, may influence personal and altruistic fear of the police, and help to account for any racial divide in these emotions.

Whatever their sources, personal and altruistic fear of the police are both likely to be consequential (Fader, 2021; Lee \& Robinson, 2019), in the same way that other types of fear have far-reaching consequences (Warr \& Ellison, 2000). The adverse effects of negative police contact on mental health, which have now been documented in numerous studies using different types of samples and designs (Alang et al., 2021; Del Toro et al., 2019; Dennison \& Finkeldey, 2021; DeVyler et al., 2017b), may be one outcome of police-related fear. Being personally or altruistically afraid of the police is also likely to have consequences for individuals' social lives and policy attitudes. Personal fear of crime, for example, is associated with a whole host of avoidance and protective behaviors, such as limiting social activities (Lane et al., 2014; Warr, 2000). Similarly, altruistic fear of crime is associated with the implementation of various home security measures, withdrawal from local organizations, and moving intentions (Drakulich, 2015); indeed, it is even more strongly associated than personal fear of crime with certain defensive reactions, such as buying a gun, carrying a weapon, and installing deadbolts (Warr \& Ellison, 2000).

In the policing context, one type of precautionary behavior has received special attention in recent years. It occurs during social interactions with others, particularly with family members, and appears to be especially common among Black Americans: "the talk" (Gonzalez, 2019, 2020; Jealous, 2018). It involves defensive legal socialization focused on communicating to others about the necessity of distrusting and avoiding officers, and about how to keep from getting hurt in contacts with them (Gonzalez, 2019; Brunson \& Weitzer, 2011; Harris \& 
Amutah-Onukagha, 2019). This type of socialization is important not only because it may hinder the development of social capital in highly-policed communities, by leading people to selfsequester and withdraw from social life (Fader, 2021; Stuart, 2016), but also because it may crystalize an understanding of police officers as untrustworthy outsiders, or even as agents of oppression, rather than sources of help and service. Indeed, growing evidence indicates that legal socialization has lasting effects on how people view the police and law (Tyler \& Trinkner 2017; Wolfe et al., 2017). To our knowledge, however, no prior quantitative studies have measured defensive legal socialization specifically, much less examined its sources. Theoretically, personal and altruistic fear of the police should be primary factors affecting whether people have "the talk" with others whose safety they care about.

We also know that in many domains, personal and altruistic fear powerfully affect individuals' policy attitudes. Personal fear of crime, for instance, is associated with punitiveness (Baker et al., 2015; Simmons, 2017), personal fear of protesters with support for police repression (Metcalfe \& Pickett, 2021), personal fear of terrorism with support for extreme, ethnically-biased, anti-terrorism policies (Haner et al., 2019). A large body of evidence also shows that altruistic fear is distinct from personal fear, is often more common and more intense, and is at least as consequential (Drakulich, 2015; Heber, 2009; Warr \& Ellions, 2000). Altruistic fear of COVID-19 (of others getting sick), for example, is associated with support for releasing inmates during the pandemic (Ivanov et al., 2021), altruistic fear of crime with support for harsh sanctions (Budd et al., 2017), and altruistic fear for school children and personnel is associated with support for gun control and school safety programs (Burton et al., 2021). It is probable, then, that both personal and altruistic fear of the police will have important influences on attitudes toward policing policies. 
After George Floyd's killing, calls grew for wholesale policing reforms, such as defunding or even disbanding the police (Weichselbaum \& Lewis, 2020). "Yes, we mean literally abolish the police," one proponent wrote in the New York Times, going on to argue that "we can't reform the police. The only way to diminish police violence is to reduce contact between the public and the police ... Fewer police officers equals fewer opportunities for them to brutalize and kill people" (Kaba, 2020, p. 1). Although only a minority of the public supports either defunding — shifting money from policing to social services—or disbanding the police, support for both policies is higher among Black Americans (Crabtree, 2020). This is understandable as Black Americans have long faced the difficult situation of having to rely on the police, who they distrust and expect to respond inappropriately (Bobo \& Thompson, 2006), for crime prevention and protection (Hagan et al., 2018). For example, only a minority of Black Americans want police to spend less time in their neighborhoods (Saad, 2020). Nevertheless, it seems likely that fear of the police, which should be most prevalent among Black Americans (Graham et al., 2020a), will increase support for defunding or even disbanding the police.

\section{THE CURRENT STUDY}

Few prior studies measured fear of the police. Those that did used data collected before George Floyd's killing and either focused on subnational populations (e.g., Chicago residents) or used single-item measures of fear (e.g., Alang et al., 2021; Graham et al., 2020a; Schuck et al. 2008). None have separately analyzed personal and altruistic fear, even though the two emotions are distinct and may differ in their prevalence, intensity, sources, and degree of influence on individuals' lives and attitudes (Drakulich, 2015; Graham et al., 2020b; Burton et al., 2021). For example, even people who are not afraid for themselves are often still afraid for their family

members (Warr \& Ellison, 2000), describing their victimization as "the worst thing that could 
happen" (Heber, 2009, p. 257). In our study, we develop separate measures of personal and altruistic fear of the police, following best practices for measuring fear-asking specifically about emotions, avoiding hypothetical phrasing, and using multiple items that cover different dimensions of the respective concepts (Ferraro, 1995). The measures we use are nearly identical to those used in past studies to measure personal and altruistic fear in other contexts (e.g., Burton et al., 2021; Graham et al., 2020b; Ivanov et al., 2021; Pickett et al., 2018a).

The goal of our study is to make four contributions to the literature. One is to provide evidence about the prevalence of both personal and altruistic fear of the police in the United States. Another is to provide evidence about the sources of both types of police-related fear, and on this front, we focus on testing the vulnerability and victimization models. Per the vulnerability model, we test the hypothesis that Black Americans will be the racial/ethnic group that is most afraid of the police, both personally and altruistically, and that the relationships between race and both fear types will be partly direct. Per the victimization model, we also test the hypothesis that the relationships between race and the two types of police-related fear will be partly indirect through past personal and vicarious experiences with mistreatment. Although our focus is on the vulnerability and victimization models, our goal is to provide a comprehensive analysis of the sources of police-related fear, and thus we also include measures corresponding to the media cultivation and neighborhood context models.

The third contribution of our study is to provide evidence about the consequences of police-related fear. Here we test four hypotheses. The first is that both personal and altruistic fear will be positively associated with defensive legal socialization. The second is that both types of fear will also be positively associated with support for defunding the police. The third is that Black Americans will be more likely than White Americans to engage in defensive legal 
socialization and to support defunding the police. The fourth is that the relationships between race and these outcomes will both be indirect through personal and altruistic fear of the police.

The fourth contribution of our study is to provide evidence about how frightening specific types of police contact are to Americans. The motivation for this part of the study is more practical or policy-oriented than theoretical. As Manski and Nagin (2017) argued, evaluating confrontational policing tactics, such as stop-and-frisk, requires considering their social costs, including their noxiousness for innocents and the fear they may cause. We use an experimental method, Rawlsian cost-benefit analysis (Scurich, 2015; Stevenson \& Mayson, 2021), to quantify the degree to which the types of police contacts involved in such tactics frighten citizens - do they frighten them as much as criminal victimization? If so, the use of confrontational stops and searches to prevent crime may be as traumatizing to civilians, and especially to Black civilians, as crime itself.

\section{DATA AND METHODS}

To investigate the prevalence, sources, and consequences of police-related fear in the United States, we surveyed a nationwide sample of Americans $(\mathrm{N}=1,150)$, matched and weighted to population parameters by YouGov, the polling firm that fields Harvard University's Cooperative Election Study (Ansolabehere \& Rivers, 2013) and The Economist's election polls. Studies have shown that YouGov's sample-matching methodology produces high-quality data (Ansolabehere \& Schaffner, 2014; Graham et al., 2021; Simmons \& Bobo, 2015). For example, data collected by FiveThirtyEight, an aggregator of election polls, shows that YouGov surveys called $89 \%$ of political races correctly, which is more than surveys by Gallup (69\%), Sienna College (73\%), IPSOS (75\%), Emerson College (76\%), Monmouth University (78\%), Suffolk University (81\%), Quinnipiac University (82\%), or Marist College (83\%). More importantly, the 
policing attitudes in our sample and the racial differences in those attitudes both appear to be similar to those in the general population (see Table $S 1$ in the online supplement).

YouGov administered our survey in 2021 , both to a general population sample $(\mathrm{N}=700)$ and to an oversample of Black respondents $(\mathrm{N}=450)$, to ensure that the total number of Black $(\mathrm{N}=517)$ and non-Hispanic White $(\mathrm{N}=492)$ respondents in the combined sample would be sufficient for meaningful comparisons by race. For both samples, YouGov used a two-step sample-matching procedure (Ansolabehere \& Rivers, 2013). For the general population sample, YouGov used a synthetic sampling frame (SSF) constructed from the American Community Survey to select matched respondents from its online panel (2 million US panelists). The matching variables were race, gender, age, and education. To correct for imperfect matching, the matched cases were weighted to the SSF using propensity scoring (based on region of residence and the matching variables), and the weights were then post-stratified on 2020 Presidential vote choice, and a four-way stratification of gender, age, race, and education. The sampling procedure was the same for the Black oversample, and, except for race, the same matching and weighting variables were used.

\section{FEAR OF THE POLICE}

For our survey, we developed original measures of both personal and altruistic fear of the police (see the Appendix). In so doing, we followed best practices for measuring fear (Ferraro, 1995), and we modeled our measures on those used in recent studies to examine similar emotions in other contexts (e.g., Burton et al., 2021; Pickett et al., 2018a). To measure personal fear, we asked respondents about their emotional fear "that the police will do the following things to you without good reason in the next five years." They rated how afraid they were $(0=$ very unafraid, 4 = very afraid) of falling victim to ten types of police mistreatment (e.g., "punch or kick you," 
"pepper spray you," "kill you"). The full list of items and exact question wording are provided in the Appendix. We averaged the ten items to construct an index (loadings: .823 to $.958, \alpha=.98$ ) on which higher values indicated greater personal fear. To measure altruistic fear, we asked how often $(0=$ very rarely, $4=$ very often $)$ the respondents "worry about the police hurting the following people," and listed seven groups (e.g., "your family members," "your friends," "your neighbors"). The seven items were averaged to form an index (loadings: .714 to $.877, \alpha=.93$ ) on which higher values indicated greater fear. ${ }^{3}$

\section{PAST POLICE MISTREATMENT}

The primary mediator of interest in our analysis of the relationship between race and police-related fear was past experience, personal or vicarious, with police mistreatment (Hagan et al., 2005; Weitzer \& Tuch, 2006). Similar to previous studies (Weitzer \& Tuch, 2006; Pickett et al., 2018b), we measured experienced mistreatment with six questions that asked how many times $(0=$ never, $3=$ three times or more $)$ police officers had done the following things either to the respondents or to their family members and close friends: stopped them without good reason, used insulting language with them, and used excessive force against them. We averaged the responses to these items to construct an index (loadings: .698 to $.848, \alpha=.90$ ) on which higher scores indicated more past experience with mistreatment. For this measure and those discussed below, the online supplement provides the full list of items, the coding procedure, and the exact question wording.

\footnotetext{
${ }^{3} \mathrm{~A}$ promax-rotated factor analysis showed that the items measuring personal and altruistic fear of the police load on two different factors. They also load separately from the items measuring fear of crime.
} 


\section{OTHER THEORETICAL SOURCES OF FEAR}

Consistent with prior research (Baranauskas \& Drakulich. 2018; Roche et al., 2016; Simmons, 2017), we measured overall news exposure as the number of days each week the respondents watched television news or looked at news on the internet. Similar to previous studies (Jackson \& Bradford, 2009; Nix et al., 2015; Pickett et al., 2018b), we measured neighborhood conditions perceptually. We included four neighborhood measures: disorder (index of six items, loadings: .659 to $.801, \alpha=.89$ ), collective efficacy (index of six items, loadings: .687 to $.784, \alpha=.88$ ), police visibility (index of four items, loadings: .519 to $.810, \alpha=$ .78), and percent Black (0-100\%). Controlling for perceived racial composition was important not only because it may influence respondents' perceptions of local crime, but also because it may influence their views about their neighbors' vulnerability to racially biased policing.

\section{CONSEQUENCES OF FEAR}

We explored two potential outcomes of police-related fear: intentions to engage in defensive legal socialization (loadings: .692 to $.844, \alpha=.87$ ) and support for defunding the police $(r=.549, \alpha=.70)$. The questions about defensive legal socialization asked how likely $(0=$ very unlikely, 4 = very likely) it was that respondents would do four things if they had a new family member, such as a new child or grandchild: 1) "advise them to stay away from police officers," 2) "teach them how to protect themselves from police officers," 3) "tell them they cannot trust police officers," and 4) "discuss with them how to keep from getting hurt if stopped by police officers." The questions about police defunding asked how much respondents supported $(0=$ strongly oppose, $4=$ strongly support $): 1)$ "cutting funding for the police and using that money instead to help communities develop service programs (e.g., drug treatment, 
mental health care)," and 2) "disbanding the police entirely and replacing them with social workers."

\section{CONTROL VARIABLES}

In the full regression models, in which we tested for mediation, we controlled for factors that prior theoretical or empirical work suggests might be related to our outcome variables (Ferraro, 1995; Lane et al., 2014; Graham et al. 2020a; Pickett et al., 2018n; Weitzer \& Tuch, 2006). The controls included residential context (urbanicity and region) as well as sociodemographic, economic, political, and religious factors. To account for individualdifferences in general fearfulness, the models also controlled for fear of crime. Importantly, in order to compare personal fear of crime to fear of the police, we measured it using the same response scale, the same five-year window, and five serious criminal offenses (e.g., "break into your house," "rob or mug you on the street," "murder you"). As with fear of the police, we averaged the items to construct an index (loadings: .747 to $.860 ; \alpha=.91$ ). The full question wording for each of the controls is provided in the online supplement, and Table S2 shows the weighted descriptive statistics for all variables used in the regression models.

\section{RAWLSIAN COST-BENEFIT EXPERIMENT}

Beyond investigating generalized personal and altruistic fear of the police, we also examined how afraid respondents were of specific types of police contact. To do this, we used an experimental design and Rawlsian cost-benefit analysis, a contingent valuation procedure that measures relative preferences for events (Scurich, 2015; Stevenson \& Mayson, 2021). As Stevenson and Mayson (2021, p. 25) explained, the advantage of this procedure "over traditional contingent-valuation surveys" is that "it avoids the need to quantify each harm in dollars." We 
asked respondents whether they would rather be the victim of a serious felony (randomly assigned: robbery or burglary) or experience one of three types of unprovoked ("without good reason") police contact (randomly assigned: questioned, searched, or arrested). ${ }^{4}$ The full question wording for this experiment is provided in the online supplement (Table S4). Because the results were similar by crime, we combined the crime conditions in the analysis.

\section{ANALYTIC STRATEGY}

The data were weighted for the univariate and bivariate analyses. For the multivariable models predicting police-related fear or the consequences of fear, we combined the general population sample and the Black oversample. All of the dependent variables were rescaled to range from 0 to 100 so that the regression coefficients could be interpreted as percentage point changes. ${ }^{5}$ All of the regression models were estimated using ordinary least squares regression, with robust standard errors to correct for heteroskedasticity. Multicollinearity was not problematic in any of the models: the largest variance inflation factor (VIF) was 2.90, and the mean VIF was 1.68. Because the full regression models included most of the covariates used to construct the weights, and because weight association tests showed that weighting the data did not significantly improve model fit (Bollen et al., 2016), we used unweighted data for the regression models. This decision did not affect the main findings. Weighted regression models yielded substantively identical conclusions.

\section{RESULTS}

\section{THE RACIAL DIVIDE IN FEAR OF THE POLICE}

\footnotetext{
${ }^{4}$ It is certainly true that felony victimization and police contact are not mutually exclusive, as officers can assault, rob, or even kill civilians.

${ }^{5} \mathrm{We}$ did this using the "norm" command in Stata 15. The equation for rescaling (normalizing) the outcomes was: $([\mathrm{Y}-\mathrm{Ymin}] \div[\mathrm{Ymax}-\mathrm{Ymin}]) \times 100$.
} 
The first portion of our analysis examines the prevalence of police-related fear by race, and the findings here are striking. Figure 1 shows the distributions of personal fear of the police among White and Black respondents, and among other racial/ethnic minorities. ${ }^{6}$ Consistent with the vulnerability model, personal fear is widespread among Black respondents, uncommon among White respondents, and respondents in other racial/ethnic groups fall in between. It would be difficult to overstate the Black-White divide in police-related fearfulness $(d=.97, t=15.40, p$ $<.001)$. Black respondents are also significantly more afraid than those in other racial and ethnic groups $(d=.21, t=2.63, p<.01)$. However, focusing on the pervasiveness of personal fear tells only part of the story. Equally important is the intensity of fear. For example, $42 \%$ of Black respondents (and 30\% of other racial/ethnic minorities) are "very afraid" that the police will kill them in the next five years, compared to $11 \%$ of White respondents. In fact, the modal responses among Black and White respondents to this question are mirror opposites: "very afraid" versus "very unafraid." The same is true for the questions about being hit, pinned to the ground, tased, or pepper-sprayed by the police (see Figure S1 in the online supplement). More broadly, the Black and White distributions in overall personal fear of the police are almost mirror opposites (top left panel in Figure 1).

Even more startling is a comparison of personal fear of the police to fear of crime (see Figure 1). Although Black respondents are more afraid than their White counterparts of crime ( $d$ $=.33, t=5.20, p<.001)$, the magnitude of this difference pales in comparison to that for fear of the police ( $d=.33$ vs. $d=.97$ ). To illustrate, most Black respondents (58\%) are either "afraid" or

\footnotetext{
${ }^{6}$ There are 141 non-Black minorities in the sample, of whom 87 are Hispanic. We combine these non-Black minorities (i.e., non-Hispanic and Hispanic) because they have very similar levels of personal and altruistic fear (see Table S3 in the online supplement), being significantly less afraid than Black respondents, but being significantly more afraid than White respondents. Combining non-Black minorities also increases the sample size (and thus the precision of estimates) for the group of "other race" respondents.
} 
"very afraid" of being killed by the police, but only $34 \%$ are fearful of being murdered by criminals. In both cases, the comparable percentage for White respondents is $16 \%$. Indeed, when the two personal fear indices are differenced, most (61\%) White respondents are more afraid of crime than of the police, but most Black respondents (55\%) are more afraid of the police than of crime $(d=.70, t=11.18, p<.001)$. Other racial/ethnic groups fall in between these extremes. The police may have it as their mission "to protect and serve," but our data show that many Americans, especially Black Americans, fear them more than criminals.

[Insert Figure 1 about here]

Are Black respondents also the most fearful that the police will hurt other people? The response distributions for altruistic fear are shown in Figure 2. As with personal fear, there is a pronounced racial divide as well as a clear racial gradient. Altruistic fear is highest among Black respondents, and lowest among White respondents, with other racial and ethnic groups falling in between (Black vs. White: $d=.88, t=13.94, p<.001$; Black vs. other race/ethnicity: $d=.26, t=$ $3.36, p<.001)$. For example, a majority (51\%) of Black respondents worry "often" or "very often" about their family members being hurt by the police, compared to $9 \%$ of White respondents and $28 \%$ of those in other racial and ethnic groups. Notably, Black respondents are not just fearful for other Black Americans. Responses to a question that asked about altruistic fear for "Hispanic citizens" reveal that Black respondents are also much more afraid than White respondents for this ethnic group $(d=.56, t=8.95, p<.001){ }^{7}$ The clear takeaway is that Black and White Americans live in very different emotional worlds. Most Black Americans live in fear of the police mistreating them and hurting others whose safety they value. Comparatively few

\footnotetext{
${ }^{7}$ Black and Hispanic respondents do not differ significantly in their altruistic fear specifically for "Hispanic citizens" $(d=.09, t=1.06, p=.288)$.
} 
White Americans do so. Other racial minorities live in an emotional world that occupies a middle ground between these two extremes.

[Insert Figure 2 about here]

Given that they are the racial groups who are most and least afraid, it bears considering the prevalence of police-related fear among subgroups of Black and White Americans who might be differentially exposed to crime and policing. Figure 3 shows violin plots of the distribution of personal and altruistic fear by race, SES, and gender. Personal fear of the police is higher among low-SES than high-SES Black respondents $(d=.19, t=2.18, p=.030)$, but altruistic fear of the police is similar in the two groups $(d=.00, t=.01, p=.994)$. The same patterns by SES emerge among White respondents $(d=.33, t=3.66, p<.001$ and $d=.05, t=.56, p=.575$, respectively $)$. Personal fear may be higher among low-SES respondents, both Black and White, because they have greater exposure to aggressive policing in high crime areas but feel less in control of policecontact outcomes (e.g., less able to hire a lawyer). ${ }^{8}$ That personal but not altruistic fear varies significantly by SES in both racial groups reinforces the point that even people who are not afraid for themselves may still be afraid for others whose safety they care about. The findings for gender show that neither personal nor altruistic fear vary significantly across Black men and women $(d=.11, t=1.29, p=.197$ and $d=.16, t=1.80, p=.073$, respectively). Among White respondents, personal fear also does not vary significantly by gender $(d=.07, t=.73, p=.464)$, but altruistic fear is significantly higher among women $(d=.18, t=2.02, p=.044)$.

What is most important about the findings in Figure 3, however, is that they show how much more prevalent police-related fear is among Black than White respondents, regardless of their SES or gender. It is not simply that the means differ by race in every subgroup, which could

\footnotetext{
${ }^{8}$ For example, SES is significantly and negatively correlated with neighborhood police visibility among both Black and White respondents $(r=-.154, p<.001$ and $r=-.127, p<.01$, respectively).
} 
reflect the influence of outliers (it does not). Instead, it is that the overall distributions of personal and altruistic fear are always nearly mirror opposites among Black and White respondents. In every subgroup, most Black respondents are afraid, but most White respondents are not. For example, $50 \%$ of high-SES Black respondents, compared to $11 \%$ of high-SES White respondents, are personally afraid of being killed by the police. In fact, both personally and altruistically, high-SES Black women are far more afraid than low-SES White men of the police ( $d=.62, t=4.39, p<.001$ and $d=1.09, t=7.74, p<.001$, respectively). The evidence thus demonstrates that police-related fear is ubiquitous in Black America, reaffirming the fact that neither class nor gender exempts Black Americans from criminalization (Anderson, 2011).

[Insert Figure 3 about here]

\section{THE SOURCES OF FEAR}

Why are Black respondents so afraid of the police? The victimization model indicates that past mistreatment should mediate the effect of race on personal and altruistic fear, whereas the media cultivation and neighborhood context models point to alternative explanations for the racial divide. To test these models, we estimate three linear regressions predicting each of the two fear indices. The first provides a baseline and includes only race, gender, and age. The second adds the media cultivation and neighborhood context variables as well as the controls. The third includes past experiences with police mistreatment.

The findings, which are shown in Figure 4, again reveal a "racial gradient" (Hagan et al., $2005)$ in both types of police-related fear: Black respondents are the most afraid, White respondents are the least afraid, and other racial/ethnic minorities fall in-between. In the baseline models, the adjusted differences in means between Black and White respondents are significant $(p<.001)$ and substantial, exceeding 20 percentage points (well over half a standard deviation in 
the outcomes). Although reduced in size, the Black-White divide in fear persists after adding the media cultivation, neighborhood context, and control variables. It also persists in the full models after accounting for experienced police mistreatment. In the full models, the Black-White disparity is 16 points for personal fear and 8 points for altruistic fear $(p<.001$ for both).

The full models explain nearly $50 \%$ of the variation in both outcomes. Notably, in the full models, overall news consumption is not significantly associated with either type of fear, but neighborhood police visibility is positively associated with both fear types (personal fear: $b=$ 2.95, $p<.011$; altruistic fear: $b=4.54, p<.001)$. These findings are inconsistent with the idea that fear simply reflects media bias and instead support the position the individuals' fears reflect their lived reality. Most importantly, one of the strongest predictors of both types of fear is past experience with police mistreatment (personal fear: $b=8.80, p<.001$; altruistic fear: $b=7.51, p$ <.001). Black respondents also report experiencing far more police mistreatment than Whites $(d$ $=.70, t=11.18, p<.001)$. Bootstrapped mediation tests reveal that past mistreatment mediates $18 \%$ of the Black-White disparity in personal fear (indirect effect: $b=3.42, p<.001$ ) and $26 \%$ of the disparity in altruistic fear (indirect effect: $b=2.92, p<.001$ ). Both results are reasonably robust to violations of the sequential ignorability assumption $(\rho \geq .25)$. Notably, much of the race effect on fear is direct, likely reflecting felt vulnerability due to broadly shared historical memories of police mistreatment (McCarthy et al., 2020).

[Insert Figure 4 about here]

\section{THE CONSEQUENCES OF FEAR}

The next portion of the analysis explores two potential consequences of police-related fear: support for defunding the police and intentions to engage in defensive legal socialization. For each outcome, we estimate two linear regressions in order to test whether police-related fear 
mediates the effects of race and police mistreatment. One is the full specification from the earlier analysis (in Figure 4). The other model adds the two measures of police-related fear. The results from both models are shown in Figure 5. The top panel shows the regression coefficients for the two fear indices from the full regression models, along with the adjusted predictions from those models at varying levels of fear (with other variables set to their means). The bottom panel shows the coefficients for race and past mistreatment from both the reduced and full models.

The models including police-related fear explain over $50 \%$ of the variation in both outcomes, and the fear variables are among the strongest predictors in the models. Both types of police-related fear are associated with increased support for defunding the police $(b=.16, p$ $<.001$ and $b=.27, p<.001)$. Going from the lowest (0) to the highest (100) level of personal and altruistic fear increases predicted support for defunding by 16 percentage points (over half a standard deviation) and 27 points (nearly a standard deviation), respectively. Both types of fear are also associated with intended defensive legal socialization $(b=.21, p<.001$ and $b=.21, p<$ .001). For both types of fear, going from the lowest to the highest level increases predicted defensive legal socialization by about 21 points, over half a standard deviation in the outcome.

Before including police-related fear in the models, Black respondents and those who had experienced more police mistreatment expressed greater support for defunding the police $(b=$ 6.77, $p<.001$ and $b=3.98, p<.001)$ and intentions to engage in defensive legal socialization $(b$ $=20.20, p<.001$ and $b=7.93, p<.001)$. These effects are reduced after including personal and altruistic fear. Bootstrapped mediation tests show that police-related fear mediates $71 \%$ of the Black-White disparity in support for defunding the police (indirect effect: $b=4.83, p<.001$ ), and $25 \%$ of the disparity in socialization (indirect effect: $b=5.10, p<.001$ ). For past mistreatment, police-related fear mediates $88 \%$ of its effect on support for defunding the police 
(indirect effect: $b=3.49, p<.001$ ), and $43 \%$ of its effect on socialization (indirect effect: $b=$ $3.43, p<.001)$. These indirect relationships are all reasonably robust to violations of the sequential ignorability assumption $(\rho \geq .37)$. The findings thus show that police-related fear is consequential and helps to account for differences across Americans in how they view the role of policing both in society and in their lives.

[Insert Figure 5 about here]

\section{CONTACT-SPECIFIC FEAR}

If most Black Americans are generally afraid of being mistreated by the police, a key question that follows is: How frightened are they of having specific types of unprovoked contact with the police? As Figure 6 shows, in the Rawlsian cost-benefit experiment, there is a significant effect of the type of police contact on evaluations $\left(V=.19, \chi^{2}=40.82 p<.001\right)$. Respondents view police questioning as the least frightening type of contact and arrest as the most frightening. Most important, evaluations differ significantly by race $\left(V=.16, \chi^{2}=30.14, p\right.$ $<.001$ ), showing a clear racial divide as well as a clear racial gradient. The prospect of police contact is most frightening to Black respondents and is least frightening to White respondents, with other racial and ethnic groups falling in between.

Strikingly, $45 \%$ of Black respondents prefer to be robbed or burglarized than to be questioned by the police "without good reason." About $18 \%$ of White respondents feel this way. ${ }^{9}$ Although differences narrow for other types of police contact, racial disparities persist: $52 \%$ of Black respondents versus $36 \%$ of White respondents prefer crime victimization over being

\footnotetext{
${ }^{9}$ The preference for crime victimization may reflect a belief that it would be over quickly whereas the consequences of police questioning might last longer (Stevenson \& Mayson, 2021). Supplementary analyses reveal that among both White and Black respondents, personal fear of the police significantly predicts the preference for crime victimization over police contact. Factors such as past crime victimization, age, education, income, and neighborhood conditions are not significantly related to this preference in either racial group.
} 
searched, and $60 \%$ of Black respondents versus $51 \%$ of White respondents prefer it over being arrested. The implication is clear: being questioned or searched by the police is frightening to many Americans, and especially to Black Americans, and thus it is very likely to be traumatizing (Del Toro et al., 2019; Lewis \& Wu, 2021). This finding makes the fact that some Americans are handcuffed and searched multiple times per year only to be released without charge each time all the more concerning (Stuart, 2016) — in their psychological effects, these repeated police searches may be similar to robbing civilians repeatedly.

[Insert Figure 6 about here]

\section{SUPPLEMENTARY ANALYSES: DISAGGREGATED BY GENDER}

Given gender differences in other types of fear (Lane et al., 2014; Pickett et al., 2018a) and gender differences in exposure to police violence (Edwards et al., 2019), we re-estimate the analyses separately for men and women. The results are the same in each group (Figures S3-S8 in the online supplement): 1) race and past mistreatment are significantly associated with both types of police-related fear; 2) there are significant indirect relationships between race and both types of police-related fear via past mistreatment; 3) both personal and altruistic fear are significantly associated with support for defunding the police and with defensive legal socialization; 4) both race and past mistreatment are significantly and indirectly associated (through police-related fear) with support for defunding the police and with defensive legal socialization; 5) there is a significant relationship between race and contact-specific fear-Black men and women are both more likely than their White counterparts to prefer criminal victimization over unprovoked police contact. Indeed, the only notable gender difference to emerge from the disaggregated analyses is that women are significantly more likely than men to prefer criminal victimization over unprovoked police contact. 


\section{DISCUSSION}

Police-related fear is at the heart of the police legitimacy crisis in America, even though it has for too long been at the periphery of policing scholarship, only rarely receiving theoretical or empirical attention. Our study sought to move police-related fear to center stage in the policing literature by measuring both personal and altruistic fear and providing a comprehensive analysis of their prevalence, sources, and consequences. Our findings show that there is an American racial divide in police-related fear and that it is immense, overshadowing the racial divide in fear of crime. Two decades ago, Silverman \& Della-Giustina (2001, p. 954) warned that "fear of police ... should not replace fear of crime." The results herein indicate that that is the exact situation facing Black Americans today. Whereas most White Americans take for granted that police are integral to their well-being and guardians of their safety, most Black Americans live in fear of the police mistreating them and hurting those they care about.

Unfortunately, some observers are likely to dismiss Black Americans' fears as exaggerated or even irrational, citing the small number of unarmed Black Americans killed by the police each year (e.g., Mac Donald, 2020). Such a dismissal misses the broader point. How many Black Americans are wrongfully arrested every year? How many are questioned or searched without good reason? How many are needlessly manhandled, pinned to the ground, or pepper-sprayed? Answers to these questions remain elusive, but countless experiments document racial discrimination in virtually every area of life — job searches, Airbnb rentals, mortgage loans, public service inquiries, etc. (Edelman et al., 2017; Giulietti et al., 2019; Hanson et al., 2016; Quillian et al., 2017). Such experiments are difficult to conduct with officers, and thus the exact level of racial bias in policing is unknown, but there is little doubt about its existence (Knox et al., 2020). What distinguishes policing from other contexts is not that officers have 
some unique insensitivity to racial stereotyping, but rather that they have unparalleled discretion, legal authority, qualified immunity, and weapons. Black Americans also stand to lose much more from racial bias in policing than just a job opportunity or a vacation rental-they stand to lose their freedom or even life. Therefore, as long as any racial bias exists in policing, and as long as officers' behavior is unpredictable (Fader, 2021; Weaver et al., 2019), Black Americans' fear of the police is not irrational and the racial divide in fear is understandable.

Additionally, a large body of qualitative research documents the habitual manner in which officers harass and treat Black Americans as suspects through pedestrian and traffic stops (Brunson, 2007; Brunson \& Miller, 2006; Jones, 2014). Common forms of police violence during these interactions include "pushing, shoving, punching, kicking, and the use of mace" (Brunson, 2007, p. 87), which are often combined with belligerent and antagonistic language, with the perceived intent of provoking community members so that officers can use violence (Weitzer \& Brunson, 2009). There is strong evidence that officers are more likely to disrespect Black than White civilians (Voigt et al., 2017). Similarly, police searches are "physically intrusive" (Brunson, 2007, p. 81; Brunson \& Miller, 2006, p. 540) and degrading (Jones, 2014), yet routinized for Black Americans. Some involve sexual misconduct or threats of sexual violence from officers (Brunson \& Miller, 2006; Brunson \& Gau, 2015). Furthermore, police violence is sometimes externalized when, for example, officers take possession of Black Americans, transport them to gang territory, and then strand them there (Brunson, 2007). Such qualitative findings make clear that using one statistic — such as the number of unarmed Black Americans killed annually by police - to dismiss Black Americans' fears is to set up a straw man designed to distract attention from the much more common, day-to-day forms of police mistreatment that terrify Black Americans and harm their mental as well as physical health. 
To identify the sources of the racial divide in police-related fear, we tested four theoretical models. Consistent with the vulnerability model, the findings reveal that much of the racial divide in both personal and altruistic fear is direct, likely reflecting a cultural awareness of objective patterns of exposure to police violence (Edwards et al., 2019) and of the historical role of policing in Black subordination (McCarthy et al., 2020; Weitzer \& Tuch, 2006). Consistent with the victimization model, the findings also show that past experience with police mistreatment is a strong predictor of personal and altruistic fear, and mediates part of the racial divide in both types of police-related fear. Consistent with the neighborhood context model, the visibility of officers in one's neighborhood, an environmental factor that likely serves as a sign of police danger, is positively associated with both types of fear. However, the racial divide in fear persists even after accounting for neighborhood conditions. On the other hand, and contrasting the media cultivation model as well as past work on policing attitudes (rather than emotions), overall news exposure is not significantly related to either type of fear. This is true in the full sample and for Black respondents (not shown). What this suggests is that Black Americans' police-related fears may be rooted mostly in their lived reality and cultural understanding of American policing.

Our analysis of the consequences of police-related fear reveals that personal and altruistic fear are both consequential, influencing Americans' policy attitudes and socialization practices. Americans who are afraid of the police are more likely to support wholesale policing reforms, like defunding or even abolishing the police. Additionally, the findings reveal that the reason Black Americans are more supportive than White Americans of such reforms is that they are more afraid of the police. Similarly, both personal and altruistic fear are positively associated with defensive legal socialization - that is, with having "the talk" - and part of the reason that 
Black Americans are more likely to engage in such socialization is that they are more afraid of the police. The importance of this finding cannot be overstated. Although not focusing on defensive legal socialization specifically, past work shows that legal socialization has sizable and long-term effects on individuals' views about the police and law (Tyler \& Trinkner 2017; Wolfe et al., 2017). Defensive legal socialization is likely to have similar effects, with parental fear influencing offspring's attitudes toward police, social activities, and behavior in interactions with officers. Future research is needed that examines this possibility.

Given the theoretical and empirical importance of police-related fear, which we demonstrate herein, and the near-complete absence of prior work on it, the avenues of inquiry that should be explored in future research are numerous. For example, we do not know what factors explain contact-specific fear or why even some White Americans prefer crime victimization over being questioned or searched by the police. Similarly, although we know that civilians' behavior in police-civilian encounters influences officers' emotions and decisionmaking (Nix et al., 2017, 2019), we do not know how officers' behavior influences civilians' encounter-specific fear. Does the presence of body-worn cameras, when visible, reduce civilians' fear? Are civilians less afraid in encounters with officers of the same race? Are they less afraid in encounters with female officers? What role does fear play in civilians' decision-making in encounters with the police? It seems possible that the very tactics that officers sometimes use to gain control in encounters with civilians, such as raising their voice and issuing commands in an aggressive way, may make those interactions less predictable by fostering fear. Instances of civilians refusing to pull over until they reach well-lit, public places, and being hesitant to leave their vehicles even when officers command them to, are examples of only a few of the possible consequences of encounter-specific fear (Foreman, 2021). Similarly, it seems likely that police 
militarization and the use of riot gear are likely to increase fear, both in specific situations and generally (Mummolo, 2018).

The policy implications of our findings are fourfold. First, despite the fear-related racial gap in support levels observed in our study, only a minority of Black (15\%) and White (8\%) respondents supported disbanding the police entirely (Table S1). Similarly, a slim majority (51\%) of Black respondents, and $29 \%$ of White respondents, supported diverting police funding to social services. Thus, in addition to the practical difficulties of disbanding or defunding the police (Lum et al., 2021), it appears that public support for doing either is not strong. Past research found that most Black Americans believe policing is a cost-effective way to control crime and want police patrols (Metcalfe \& Pickett, 2018; Saad, 2020). Clearly, however, reforms are needed to reduce racial bias in policing and police mistreatment of civilians. One particularly promising reform that should be pursued is police racial and gender diversification. Ba et al. (2021, p. 701) found that White male officers were the most likely to harass and use force against Black civilians and concluded that their "results strongly suggest that diversification can reshape police-civilian encounters." Beyond implementing reforms, the police also need to do a better job listening to Black Americans' concerns and providing information about the steps they are taking to address them — the current police response is often silence (Chen, 2020).

Second, in evaluating and improving policing tactics, it is important to consider the distress they cause civilians and how to reduce it, not just how they affect crime rates (Manski \& Nagin, 2017). Nearly two decades ago, Sherman (2003, pp. 25-26) argued that the justice system must become "emotionally intelligent in all of its interactions" with civilians, emphasizing that "understanding how to avoid provoking [negative] emotions ... may be more important than understanding how to instill a desire to obey the law." Our findings are consistent with 
Sherman's argument, showing that for many Americans, and especially for Black Americans, being questioned or searched by the police without receiving a good explanation is worse than being robbed or burglarized. Because using the worst of two evils to prevent the lesser one is destructive — as well as emotionally unintelligent—ensuring that good reasons exist for officers' actions and that they are provided to civilians should be a priority.

Third, and related, procedural justice training, which encourages officers not just to explain their actions to civilians but also to treat them respectfully, fairly, and with dignity, may improve officer behavior and reduce public fear (Wood et al., 2020). The evidence is mixed as to whether experiencing procedural justice influences civilians' general perceptions of the police (Mazerolle et al., 2013; Sahin et al., 2017). Even if it does not affect general perceptions, however, it might still reduce fear-again, it is critical "to recognize elementary distinctions between perception, cognition, and emotion" (Warr, 2000, p. 453). Fourth, there should be efforts to foster positive, non-enforcement contacts between Black Americans and the police, as these interactions may help to reduce anxiety and improve attitudes (Peyton et al., 2019; Freiburger, 2019).

Our study is not without limitations, which provide opportunities for future research. First, similar to most previous studies, we used measures of overall news consumption rather than measuring exposure to specific content types (e.g., policing news). Given the intensity with which police violence has been covered in the news (across networks and media types), it seems reasonable to treat overall consumption as a proxy for exposure to policing content. Nevertheless, future studies should explore whether exposure specifically to policing news is associated with police-related fear. Second, our study is cross-sectional, meaning that unless the causal order between variables is established by their natural time ordering, as it is for race, it 
can only be assumed based on theory or question wording (e.g., for the relationship between fear and socialization intentions). Additional studies are thus needed that explore the relationships examined herein with longitudinal data to establish the causal order empirically.

Third, although there is strong evidence supporting the generalizability of findings from YouGov surveys (Ansolabehere \& Schaffner, 2014; Simmons \& Bobo, 2015), our sample is not a probability sample of the general public - it is a matched sample of online panelists. The assumption made in using such samples is that adjusting for the matching and weighting variables (and for the covariates in the regression models) renders online selection ignorable with respect to the specific outcomes examined. We believe this is a reasonable assumption (see Table S1). However, there is some evidence that our sample may slightly overrepresent White Americans who know people who have been mistreated by the police (in comparison to Gallup data $)^{10}$, which would mean that our findings may overestimate White Americans' police-related fear and underestimate the racial divide in fearfulness. Therefore, future research should attempt to replicate our study using a probability sample.

To conclude, the different emotional worlds inhabited by White and Black Americans, and the different understandings of the police — as protectors versus aggressors - that underpin them, are indicative not only of a citizenship deficit in the United States but also of racial injustice. In a just society, police-related fear would be low in all racial groups because no one, regardless of race, would have to be afraid of being mistreated by the police. In a just society, no one would have to have "the talk" with family youths about the need to be wary of officers, who may be untrustworthy and dangerous. This is not the case in the United States. Black Americans'

\footnotetext{
${ }^{10}$ Gallup reports that $71 \%$ of Black adults and $34 \%$ of White adults know people who have been mistreated by the police (Momolu, 2020). The percentages in our data are 70\% and 43\%. The questioning was not identical, however, and the Gallup data might be less accurate than ours, as YouGov tends to outperform Gallup in election forecasting.
} 
fear of the police should be acknowledged as a criminological fact and a public health risk (Alang et al., 2021; Del Toro et al., 2019; Dennison \& Finkeldey, 2021). The deep racial divide in fear documented herein represents a stain on American democracy and its ideal of equal justice before the law. It is a "knee on the neck of justice for Black Americans" (Biden, 2021). A bipartisan effort should be made to show Black Americans that their fears are recognized, legitimate, and merit our collective concern and action. 


\section{REFERENCES}

Ang, D. (2021). The effects of police violence on inner-city students. The Quarterly Journal of Economics, 136(1), 115-168.

Alang, S., McAlpine, D., \& McClain, M. (2021). Police encounters as stressors: Associations with depression and anxiety across race. Socius, 7, 1-13.

Anderson, E. (2011). The Cosmopolitan Canopy: Race and Civility in Everyday Life. WW Norton \& Company.

Ansolabehere, S., \& Rivers, D. (2013). Cooperative survey research. Annual Review of Political Science, 16, 307-329.

Ansolabehere, S., \& Schaffner, B. F. (2014). Does survey mode still matter? Findings from a 2010 multi-mode comparison. Political Analysis, 22(3), 285-303.

Ba, B. A., Knox, D., Mummolo, J., \& Rivera, R. (2021). The role of officer race and gender in police-civilian interactions in Chicago. Science, 371(6530), 696-702.

Barkworth, J. M., \& Murphy, K. (2015) Procedural justice policing and citizen compliance behaviour: the importance of emotion. Psychology, Crime \& Law, 21(3), 254-273.

Baranauskas, A. J., \& Drakulich, K. M. (2018). Media construction of crime revisited: Media types, consumer contexts, and frames of crime and justice. Criminology, 56(4), 679-714.

Biden, J. R. Jr. (2021, April 20). Remarks by President Biden on the Verdict in the Derek Chauvin Trial for the Death of George Floyd. Retrieved from: https://www.whitehouse.gov/briefing-room/speeches-remarks/2021/04/20/remarks-bypresident-biden-on-the-verdict-in-the-derek-chauvin-trial-for-the-death-of-george-floyd/

Bobo, L. D., \& Thompson, V. (2006). Unfair by design: The war on drugs, race, and the legitimacy of the criminal justice system. Social Research, 73(2), 445-472.

Bollen, K. A., Biemer, P. P., Karr, A. F., Tueller, S., \& Berzofsky, M. E. (2016). Are survey weights needed? A review of diagnostic tests in regression analysis. Annual Review of Statistics and Its Application, 3, 375-392.

Brunson, R. K. (2007). "Police don't like black people": African-American young men's accumulated police experiences. Criminology \& Public Policy, 6(1), 71-101.

Brunson, R. K., \& Gau, J. M. (2015). Officer race versus macro-level context: A test of competing hypotheses about black citizens' experiences with and perceptions of black police officers. Crime \& Delinquency, 61(2), 213-242. 
Brunson, R. K., \& Miller, J. (2006). Gender, race, and urban policing: The experience of African American youths. Gender \& Society, 20(4), 531-552.

Brunson, R. K., \& Weitzer, R. (2011). Negotiating unwelcome police encounters: The intergenerational transmission of conduct norms. Journal of Contemporary Ethnography, 40(4), 425-456.

Brunton-Smith, I., \& Sturgis, P. (2011). Do neighborhoods generate fear of crime? An empirical test using the British Crime Survey. Criminology, 49(2), 331-370.

Budd, K., Burbrink, M., \& Miller, J. (2017). Perceptions of appropriate court-ordered sanctions for situational couple violence offenders: A pilot study. Journal of Family Violence, 32, 419-430.

Burton, A. L., Pickett, J. T., Jonson, C. L., Cullen, F. T., \& Burton, V. S., Jr. (2021). Public support for policies to reduce school shootings: A moral-altruistic model. Journal of Research in Crime and Delinquency, 58(3), 269-305.

Callanan, V. J., \& Rosenberger, J. S. (2011). Media and public perceptions of the police: Examining the impact of race and personal experience. Policing \& Society, 21(2), 167189.

Cheng, T. (2020). Input without influence: The silence and scripts of police and community relations. Social Problems, 67(1), 171-189.

Chiricos, T., Padgett, K., \& Gertz, M. (2000). Fear, TV news, and the reality of crime. Criminology, 38(3), 755-786.

Cobbina, J., LaCourse, A., Brooke, E. J., \& Chaudhuri, S. (2021). Protesting during a pandemic: Narratives on risk-taking and motivation to participating in the 2020 March on Washington. Crime \& Delinquency, 67(8), 1195-1220.

Crabtree, S. (2020). Most Americans Say Policing Needs 'Major Changes.” Washington, D.C.: Gallup. Retrieved from: https://news.gallup.com/poll/315962/americans-say-policingneeds-major-changes.aspx

Del Toro, J., Lloyd, T., Buchanan, K. S., Robins, S. J., Bencharit, L. Z., Smiedt, M. G., Reddy, K. S., Pouget, E. R., Kerrison, E. M., \& Goff, P. A. (2019). The criminogenic and psychological effects of police stops on adolescent black and Latino boys. Proceedings of the National Academy of Sciences., 116(17), 8261-8268.

Dennison, C. R., \& Finkeldey, J. G. (2021). Self-reported experiences and consequences of unfair treatment by police. Criminology, 59(2), 254-290. 
DeVylder, J. E., Frey, J. J., Cogburn, C. D., Wilcox, H. C., Sharpe, T. L., Oh, H. Y., Nam, B., \& Link, B. G. (2017a). Elevated prevalence of suicide attempts among victims of police violence in the USA. Journal of Urban Health, 94(5), 629-636.

DeVylder, J. E., Oh, H. Y., Nam, B., Sharpe, T. L., Lehmann, M., \& Link, B. G. (2017b). Prevalence, demographic variation and psychological correlates of exposure to police victimisation in four U.S. cities. Epidemiology and Psychiatric Sciences, 26(5), 466-477.

Drakulich, K. M. (2013). Perceptions of the local danger posed by crime: Race, disorder, informal control, and the police. Social Science Research, 42(3), 611-632.

Drakulich, K. M. (2015). Concerns for self or family? Sources of and responses to altruistic fear. Journal of Interpersonal Violence, 30(7), 1168-1207.

Drakulich, K. M., \& Crutchfield, R. D. (2013). The role of perceptions of the police in informal social control: Implications for the racial stratification of crime and control. Social Problems, 60(3), 383-407.

Edwards, F., Lee, H., \& Esposito, M. (2019). Risk of being killed by police use of force in the United States by age, race-ethnicity, and sex. Proceedings of the National Academy of Sciences, 116(34), 16793-16798.

Edelman, B., Luca, M., \& Svirsky, D. (2017). Racial discrimination in the sharing economy: evidence from a field experiment. American Economic Journal: Applied Economics, 9(2), 1-22.

Fader, J. (2021). "I don't have time for drama": Managing risk and uncertainty through network avoidance. Criminology, 59(2), 291-317.

Farrall, S., Jackson, J., \& Gray, E. (2009). Social Order and the Fear of Crime in Contemporary Times. New York, NY: Oxford University Press.

Ferraro, K. F. (1995). Fear of Crime: Interpreting Victimization Risk. Albany, NY: State University of New York Press.

Ferraro, K. F. (1996). Women's fear of victimization: Shadow of sexual assault? Social Forces, 75(2), 667-690.

Freiburger, T. L., (2019). Improving youths' attitudes about the police: Results from an experimental design. Criminal Justice Review, 44(4), 413-430.

Foreman, T. (2021, April 9). Lawsuit: Virginia police officers threatened man during stop. $A B C$ News. Retrieved from: https://abcnews.go.com/US/wireStory/lawsuit-virginia-policeofficers-threatened-man-stop-76982103 
Gibson, C. L., Zhao, J., Lovrich, N. P., \& Gaffney, M. J. (2002). Social integration, individual perceptions of collective efficacy, and fear of crime in three cities. Justice Quarterly, $19(3), 537-564$

Gonzalez, S. M. (2019). Making it home: An intersectional analysis of the police talk. Gender \& Society, 33(3), 363-386.

Gonzalez, S. M. (2020). Black girls and the talk? Policing, parenting, and the politics of protection. Social Problems. Published online before print. doi.10.1093/socpro/spaa032

Gottlieb, A., \& Wilson, R. (2019). The effect of direct and vicarious police contact on the educational achievement of urban teens. Children and Youth Services Review, 103, 190199.

Graham, A., Haner, M., Sloan, M. M., Cullen, F. T., Kulig, T. C., \& Jonson, C. L. (2020) Race and worrying about police brutality: The hidden injuries of minority status in America. Victims \& Offender, 15(5), 549-573

Graham, A., Pickett, J. T., \& Cullen, F. T. (2021). Advantages of matched over unmatched opt-in samples for studying criminal justice attitudes: A research note. Crime \& Delinquency, 67(12), 1962-1981,

Graham, A., Cullen, F. T., Pickett, J. T., Jonson, C. L., Haner, M., \& Sloan, M. M. (2020). Faith in Trump, moral foundations, and social distancing defiance during the coronavirus pandemic. Socius, 6, 1-23.

Giulietti, C., Tonin, M., \& Vlassopoulos, M. (2019). Racial discrimination in local public services: a field experiment in the United States, Journal of the European Economic Association, 17(1), 165-204.

Hagan, J., Shedd, C., \& Payne, M. R. (2005). Race, ethnicity, and youth perceptions of criminal injustice. American Sociological Review, 70(3), 381-407.

Hagan, J., McCarthy, B., Herda, D., \& Chandrasekher, A. C. (2018). Dual-process theory of racial isolation, legal cynicism, and reported crime. Proceedings of the National Academy of Sciences, 115(28), 7190-7199.

Haner, M., Sloan, M. M., Cullen, F. T., Kulig, T. C., \& Jonson, C. L. (2019). Public concern about terrorism: Fear, worry, and support for anti-Muslim policies. Socius, 5, 1-16.

Hanson, A., Hawley, Z., Martin, H., \& Liu, B. (2016). Discrimination in mortgage lending: Evidence from a correspondence experiment. Journal of Urban Economics, 92, 48-65,

Harrell, E., \& Davis, E. (2020). Contacts between police and the public, 2018 - statistical tables. Bureau of Justice Statics Report, NCJ 255730. Washington, DC: US Department of Justice. 
Harris, A., \& Amutah-Onukagha, N. (2019). Under the radar: Strategies used by Black mothers to prepare their sons for potential police interactions. Journal of Black Psychology, 45(67), 439-453.

Heber, A. (2009). "The worst thing that could happen": On altruistic fear of crime. International Review of Victimology, 16(3), 257-275.

Hinkle, J. C., \& Weisburd, D. (2008). The irony of broken windows policing: A micro-place study of the relationship between disorder, focused police crackdowns and fear of crime. Journal of Criminal Justice, 36(6), 503-512.

Hornsby, M. (2021). "Stranger Fruit": Black mothers and the fear of police brutality. The Marshall Project. Retrieved from:

https://www.themarshallproject.org/2021/03/22/stranger-fruit-black-mothers-and-thefear-of-police-brutality

Ivanov, S., Novisky, M. A., \& Vogel, M. (2021). Racial resentment, empathy, and support for release during COVID-19: Results from a survey experiment. Socius, 7, 1-7.

Jackson, J. (2011). Revisiting risk sensitivity in the fear of crime. Journal of Research in Crime and Delinquency, 48(4), 513-37.

Jackson, J., \& Bradford, B. (2009). Crime, policing and social order: On the expressive nature of public confidence in policing. British Journal of Sociology, 60(3), 493-521,

Jealous, B. (2018, March 13). Beyond 'the talk': How I plan to address police violence against Black communities. The Root. https://www.theroot.com/beyond-the-talk-how-i-plan-toaddress-policeviolenc-1823716888

Jones, N. (2014). "The regular routine": Proactive policing and adolescent development among young, poor black men. New Directions for Child and Adolescent Development, 2014(143), 33-54.

Katz, J. (1988). The Seductions of Crime: Moral and Sensual Attractions of Doing Evil. New York: Basil Blackwell.

Knox, D., Lowe, W., \& Mummolo, J. (2020). Administrative records mask racially biased policing. American Political Science Review, 114(3), 619-637.

Lane, J., Rader, N. E., Henson, B., Fisher, B. S., and May, D. C. (2014). Fear of Crime in the United States: Causes, Consequences, and Contradictions. Durham, NC: Carolina Academic Press. 
Lee, J. R. S., \& Robinson, M. A. (2019). "That's my number one fear in life. It's the police": Examining young Black men's exposures to trauma and loss resulting from police violence and police killing. Journal of Black Psychology, 45(3), 143-184.

Legewie, J., \& Fagan, J. (2019). Aggressive policing and the educational performance of minority youth. American Sociological Review, 84(2), 220-247.

Lewis, M. W., \& Wu, L. (2021). Exposure to community violence versus overpolicing and PTSD among African American university students, Journal of Human Behavior in the Social Environment, 31(8), 1026-1039.

Lum, C., Koper, C. S., \& Wu, X. (2021). Can we really defund the police? A nine-agency study of police response to calls for service. Police Quarterly. Advance online publication. doi: $10.1177 / 10986111211035002$

Mac Donald, H. (2020, June 2). The myth of systemic police racism. Wall Street Journal. Retrieved from: https://www.wsj.com/articles/the-myth-of-systemic-police-racism11591119883

Manski, C. F., \& Nagin, D. S. (2017). Assessing benefits, costs, and disparate racial impacts of confrontational proactive policing. Proceedings of the National Academy of Sciences, 114(35), 9308-9313.

Mazerolle, L., Antrobus, E., Bennett, S., \& Tyler, T., R. (2013). Shaping citizen perceptions of police legitimacy: A randomized field trial of procedural justice. Criminology, 51(1), 3364.

McCarthy, B, Hagan, J, Herda, D. (2020). Neighborhood climates of legal cynicism and complaints about abuse of police power. Criminology, 58(3), 510-536.

Metcalfe, C., and Pickett, J. T. (2018). The extent and correlates of public support for deterrence reforms and hot spots policing. Law \& Society Review, 52(2), 471-502.

Metcalfe, C., \& Pickett, J. T. (2021). Public fear of protesters and support for protest policing: An experimental test of two theoretical models. Criminology.

Momolu, K. (2020). Black More Likely to Know People Mistreated by Police. Washington, D.C.: Gallup. Retrieved from: https://news.gallup.com/poll/316526/black-adults-likely-knowpeople-mistreated-police.aspx?version=print

Mummolo, J. (2018). Militarization fails to enhance police safety or reduce rime but may harm police reputation. Proceedings of the National Academy of Science, 115(37), 9181-9186.

Nix, J., Pickett, J. T., \& Mitchell, R. J. (2019). Compliance, noncompliance, and the in-between: Causal effects of civilian demeanor on police officers' cognitions and emotions. Journal of Experimental Criminology, 15, 611-639. 
Nix, J., Pickett, J. T., Wolfe, S. E., \& Campbell, B. A. (2017). Demeanor, race, and police perceptions of procedural justice: Evidence from two randomized experiments, Justice Quarterly, 34(7), 1154-1183.

Nix, J., Wolfe, S. E., Rojek, J., \& Kaminski, R. J. (2015). Trust in the police: The influence of procedural justice and perceived collective efficacy. Crime \& Delinquency, 61(4), 610640.

Ouss, A., \& Rappaport, J. (2020). Is police behavior getting worse? Data selection and the measurement of policing harms. Journal of Legal Studies, 49(1), 153-198.

Peyton, K., Sierra-Arévalo, \& Rand, D. G. (2019). A field experiment on community policing and police legitimacy. Proceedings of the National Academy of Science, 116(40), 1989419898.

Pickett, J. T., Nix, J., \& Roche, S. P. (2018b). Testing a social schematic model of police procedural justice. Social Psychology Quarterly, 81(2), 97-125.

Pickett, J. T., Roche, S. P., \& Pogarksy, G. (2018a). Toward a bifurcated theory of emotional deterrence. Criminology, 56(1), 27-58.

Quillian, L., Pager, D., Hexel, O., \& Midtboen, A. H. (2017). Meta-analysis of field experiments shows no change in racial discrimination in hiring over time. Proceedings of the National Academy of Science, 114(41), 10870-10875.

Roberts, J. V., \& Stalans, L. J. (1997). Public Opinion, Crime, and Criminal Justice. Boulder, CO: Westview Press.

Roche, S. P., Pickett, J. T., \& Gertz, M. (2016). The scary world of online news? Internet news exposure and public attitudes toward crime and justice. Journal of Quantitative Criminology, 32, 215-36.

Roche, S. P., Wilson, T., \& Pickett, J. T. (2020). Perceived control, severity, certainty, and emotional fear: Testing an expanded model of deterrence. Journal of Research in Crime and Delinquency, 57(4), 493-531.

Reisig, M. D., \& Parks, R. B. (2000): Experience, quality of life, and neighborhood context: A hierarchical analysis of satisfaction with police. Justice Quarterly, 17(3), 607-630

Rosenbaum, D. P., Schuck, A. M., Costello, S. K., Hawkins, D. F., \& Ring, M. K. (2005). Attitudes toward the police: The effects of direct and vicarious experiences. Police Quarterly, 8(3), 343-365. 
Saad, L. (2020). Black Americans Want Police to Retain Local Presence. Washington, D.C.: Gallup. Retrieved from: https://news.gallup.com/poll/316571/black-americans-policeretain-local-presence.aspx

Sahin, N., Braga, A. A., Apel, R., \& Brunson, R. K. (2017). The impact of procedurally-just policing on citizen perceptions of police during traffic stops: The Adana Randomized Controlled Trial. Journal of Quantitative Criminology, 37, 701-26.

Schuck, A. M., Rosenbaum, D. P., \& Hawkins, D. F. (2008). The influence of race/ethnicity, social class, and neighborhood context on residents' attitudes toward the police. Police Quarterly, 11(4), 496-519.

Scurich, N. (2015). Criminal justice policy preferences: Blackstone ratios and the veil of ignorance. Stanford Law \& Policy Review, 26, 23-35.

Sherman, L. W. (2003). Reason for emotion: reinventing justice with theories, innovations, and research - the American Society of Criminology 2002 Presidential Address. Criminology, $41(1), 1-38$.

Silverman, E. B., \& Della-Giustina, J. (2001). Urban policing and the fear of crime. Urban Studies, 38(5-6), 941-957.

Simmons, A. D. (2017). Cultivating support for punitive criminal justice policies: News sectors and the moderating effects of audience characteristics. Social Forces, 96(1), 299-327.

Simmons, A. D., \& Bobo, L. D. (2015). Can non-full-probability internet surveys yield useful data? A comparison with full-probability face-to-face surveys in the domain of race and social inequality attitudes. Sociological Methodology, 45(1), 357-387.

Stevenson, M., \& Mayson, S. G. (2021). Pretrial detention and the value of liberty. Virginia Public Law and Legal Theory Research Paper No. 2021-14.

Stuart, F. (2016). Becoming "copwise": Policing, culture, and the collateral consequences of streetlevel criminalization. Law \& Society Review, 50(2), 279-313.

Tyler, T. R., \& Trinkner, R. (2017). Why Children Follow Rules: Legal Socialization and the Development of Legitimacy. New York: Oxford University Press.

Voigt, R., Camp, N. P., Prabhakaran, V., Hamilton, W. L., Hetey, R. C., Griffiths, C. M., Jurgens, D., Jurafsky, D., \& Eberhardt, J. L. (2017). Language from police body camera footage shows racial disparities in officer disrespect. Proceedings of the National Academy of Sciences, 114(25), 6521-6526.

Warr, M. (1984). Fear of victimization: Why are women and the elderly more afraid? Social Science Quarterly, 65(3), 681-702. 
Warr, M. (2000). Fear of crime in the United States; Avenues for research and policy. In Criminal Justice 2000: Volume 4, Measurement and Analysis of Crime and Justice, ed. Duffee, D. Bethesda, MD: National Institute of Justice.

Warr, M., \& Ellison, C. G. (2000). Rethinking social reactions to crime: Personal and altruistic fear in family households. American Journal of Sociology, 106(3), 551-578.

Weaver, V. M., Papachristos, A., \& Zanger-Tishler, M. (2019). The great decoupling: The disconnection between criminal offending and experience of arrest across two cohorts. RSF: The Russell Sage Foundation Journal of the Social Sciences, 5(1), 89-123.

Weichslbaum, S., \& Lewis, N. (2020). Support for defunding the police department is growing. Here's why it's not a silver bullet. The Marshall Project. Retrieved from: https://www.themarshallproject.org/2020/06/09/support-for-defunding-the-policedepartment-is-growing-here-s-why-it-s-not-a-silver-bullet

Weitzer, R., \& Tuch, S. A. (2006). Race and Policing in America: Conflict and Reform. New York: Cambridge University Press.

Wolfe, S. E., McLean, K. \& Pratt, T. C. (2017). "I learned it by watching you”: Legal socialization and the intergenerational transmission of legitimacy attitudes. British Journal of Criminology, 57(5), 1123-43.

Wood, G., Tyler, T. R., \& Papachristos, A. V. (2020). Procedural justice training reduces police use of force and complaints against officers. Proceedings of the National Academy of Sciences, 117(18), 9815-9821.

Wu, Y., Sun, I. Y., \& Triplett, R. A. (2009). Race, class or neighborhood context: Which matters more in measuring satisfaction with police? Justice Quarterly, 26(1), 125-156. 


\section{Table 1. Selected Quotes on Fear of the Police in Media Coverage}

\begin{tabular}{|c|c|c|}
\hline Date & Source & Quote \\
\hline $05-24-21$ & The Nation & $\begin{array}{l}\text { "One thing we seem to rarely talk about, led alone legitimate, is Black fear. Black } \\
\text { fear of police is understood —and in some ways codified (through things like use-of- } \\
\text { force policies and qualified immunity)—as illegitimate." — Joshua Adams }\end{array}$ \\
\hline $05-07-21$ & The Hill & $\begin{array}{l}\text { "Every time they get in a car by themselves, I worry about what assumption is being } \\
\text { made by somebody who doesn't know everything about them ... The fact that they } \\
\text { are good students and polite girls. But maybe they're playing their music a little loud. } \\
\text { Maybe somebody sees the back of their head and makes an assumption." - - Michelle } \\
\text { Obama }\end{array}$ \\
\hline 04-30-21 & The Guardian & $\begin{array}{l}\text { "Over the years, fears of my son falling victim to violence, at the hands of police or } \\
\text { criminals, influenced a very rigid approach to parenting during his high school years } \\
\text { that I'm not proud of." - Crystal Brooklyn }\end{array}$ \\
\hline $04-24-21$ & Fox News & $\begin{array}{l}\text { "When Black people_-a lot of Black people-are at the wheel and out in the street, } \\
\text { they fear police coming to them and they are fearful of what streetcorner justice, } \\
\text { you're tried and convicted and killed on the spot versus a White person who gets a } \\
\text { chance to go to court" - April Ryan }\end{array}$ \\
\hline $04-17-21$ & Vice News & $\begin{array}{l}\text { "People on the ground in Minnesota say they're not just frustrated with a broken } \\
\text { policing system; they're afraid for their lives." - - Samir Ferdowsi }\end{array}$ \\
\hline 04-14-21 & $\mathrm{CNN}$ & $\begin{array}{l}\text { "I'm a Black man who has never personally had a nasty run-in with the police. I } \\
\text { should have no trouble with them. But I fear them, and I know they fear me." } \\
\text { - Issac Bailey }\end{array}$ \\
\hline $04-13-21$ & $\mathrm{CNN}$ & $\begin{array}{l}\text { "He was terrified that if he was going to move his hands below where Officer } \\
\text { Gutierrez could have seen them to undo that seatbelt, they would have murdered } \\
\text { him." - Jonathan Arthur }\end{array}$ \\
\hline $04-12-21$ & NBC Bay Area & $\begin{array}{l}\text { "I have three Black sisters, a mom and dad ... Most of my friends are Black. So, it's } \\
\text { scary ... as soon as people hear cop sirens, they fear." - Eric Paschall }\end{array}$ \\
\hline $04-12-21$ & Esquire & $\begin{array}{l}\text { "Ordinary citizens living ordinary lives should not be afraid of police. But in } \\
\text { America, many are." - Charles Pierce }\end{array}$ \\
\hline $04-01-21$ & $\begin{array}{c}\text { The Washington } \\
\text { Post }\end{array}$ & $\begin{array}{l}\text { "Frazier, who is Black, told the court that when she remembers what she saw happen } \\
\text { to Floyd, she can't help but think about how her own father, brothers or uncles might } \\
\text { find themselves in a similar situation and suffer the same fate. I have the same fears } \\
\text { about my sons and myself." - Eugene Robinson }\end{array}$ \\
\hline $08-25-20$ & ESPN & "Black men, Black women, Black kids, we are terrified." —LeBron James \\
\hline $06-18-20$ & USA Today & $\begin{array}{l}\text { "I, like many other Black Americans, have found myself choking on my own fears } \\
\text { and disbelief when faced with the realities of an encounter with law enforcement." } \\
\text {-Senator Tim Scott }\end{array}$ \\
\hline $06-13-20$ & USA Today & $\begin{array}{l}\text { "From very early on, I was fearful of the police ... I can't think of a time when I } \\
\text { called the police unless it was very necessary - like a murder." - Ishia Lynette }\end{array}$ \\
\hline 03-04-20 & NBC News & $\begin{array}{l}\text { "I truly am afraid that something like what happened to George Floyd might happen } \\
\text { to anybody out here, especially my dad." - Tyson LaBlanche }\end{array}$ \\
\hline 09-01-17 & Huffington Post & $\begin{array}{l}\text { "I've been afraid of the police for the past } 10+\text { years due to witnessing police } \\
\text { brutality and abuse of power ... I'm a law-abiding, 20-something, white woman, yet } \\
\text { my heart continues to speed every time I'm around police." - Chelsea Taylor }\end{array}$ \\
\hline
\end{tabular}




\section{Figure 1. Personal Fear of the Police and Crime, by Race}
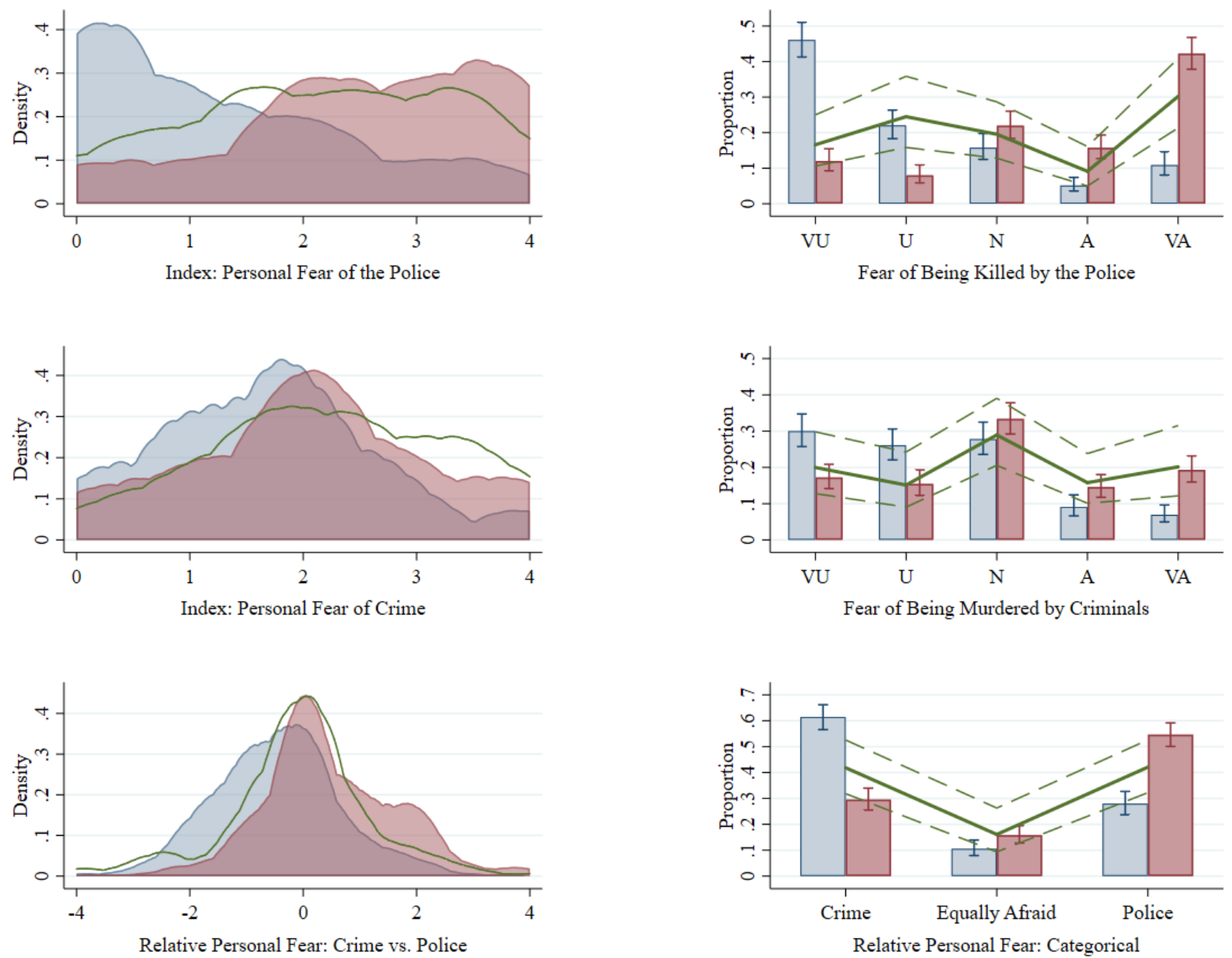

$\square$ White $\square$ Black -Other Race

NOTES: The left panels show the kernel densities for the personal fear of police index (average of 10 items) and personal fear of crime index (average of five items) indices. For illustrative purposes, the top and middle panels on the right show the distribution for one of the measures used in each index. The relative fear index is equal to the difference between the fear of police and fear of crime indices. $\mathrm{VU}=$ very unafraid, $\mathrm{U}=$ unafraid, $\mathrm{N}=$ neither afraid nor unafraid, $\mathrm{A}=$ afraid, and $\mathrm{VA}=$ very afraid. $\mathrm{N}=1,149$ to 1,150 . 
Figure 2. Altruistic Fear of the Police, by Race
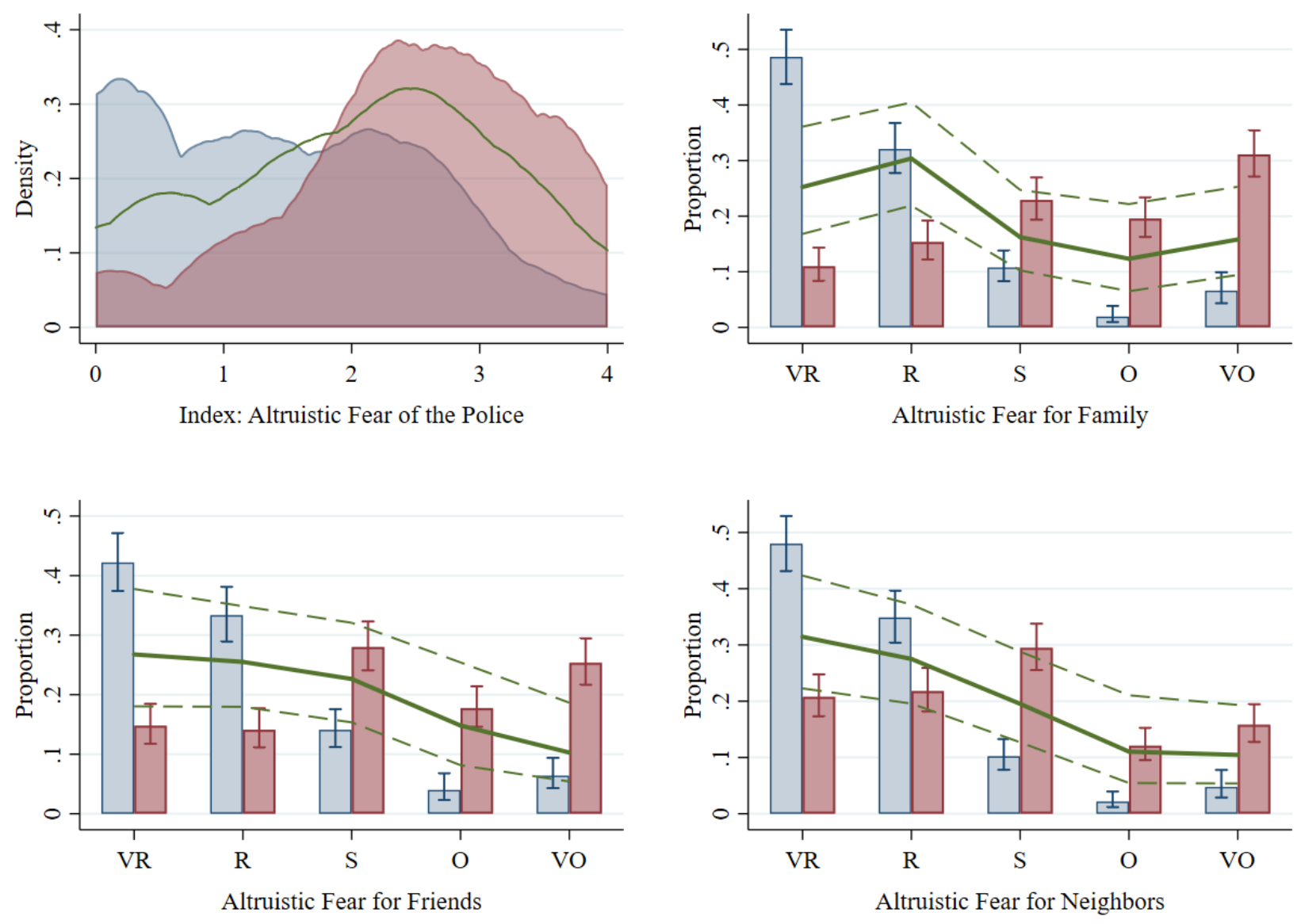

$\square$ White $\square$ Black -Other Race

NOTES: Top left panel shows kernel density for the altruistic fear index (average of seven items). Other panels show the proportions for three of the items in the index. $\mathrm{VR}=$ very rarely, $\mathrm{R}=$ rarely, $\mathrm{S}=$ sometimes, $\mathrm{O}=\mathrm{often}$, and $\mathrm{VO}=$ very often. $\mathrm{N}=1,150$. 
Figure 3. Disaggregated by Race, Socioeconomic Status, and Gender: Personal and Altruistic Fear of the Police
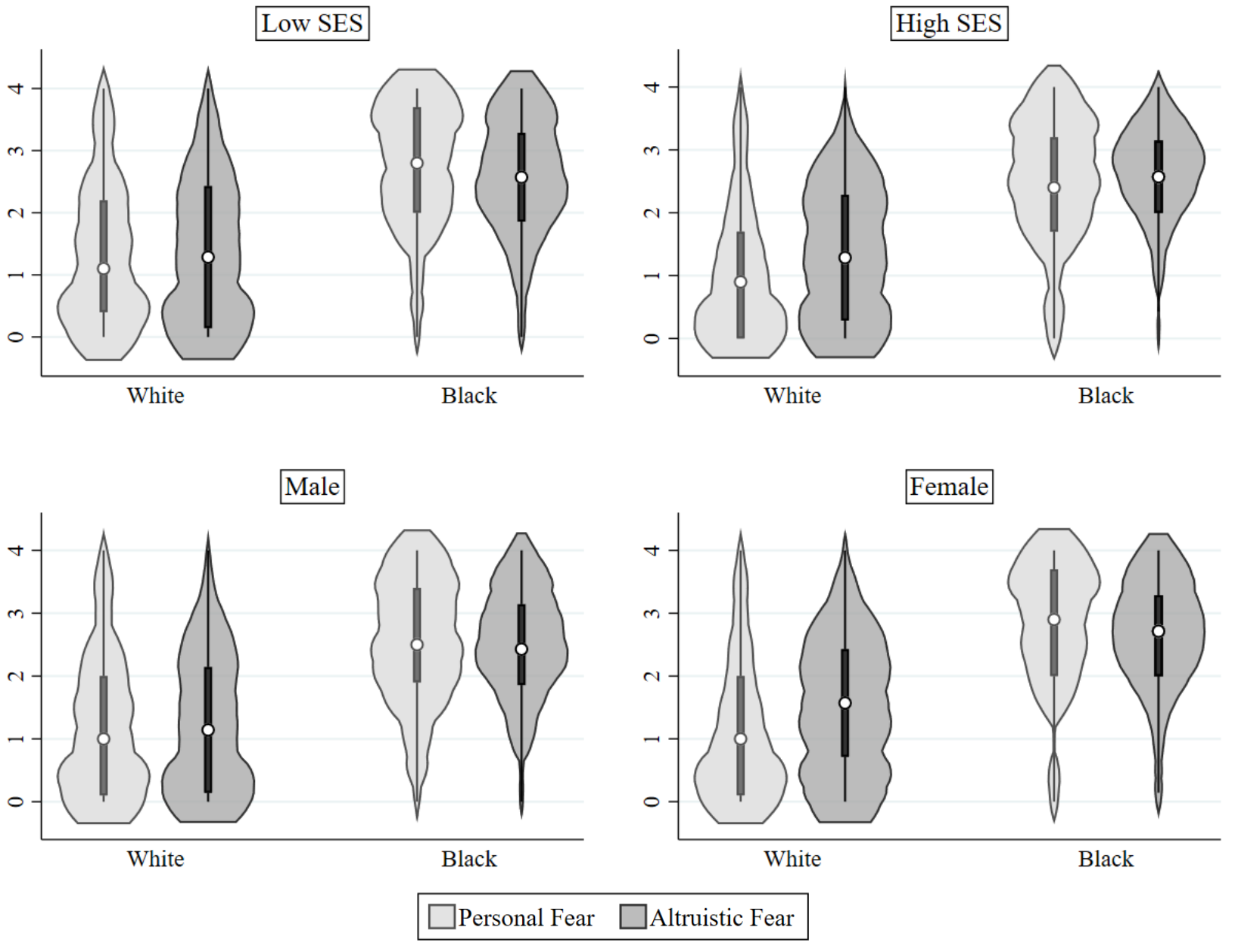

NOTES: Figure shows violin plots with circles for the median value, boxes for the interquartile range, spikes extending to the upper and lower values, and overlaid kernel densities. SES is measured as the average of education and income, with "low" versus "high" defined by at or below versus above the sample mean. $\mathrm{N}=1,009$. 


\section{Figure 4. Sources of Personal and Altruistic Fear of the Police}

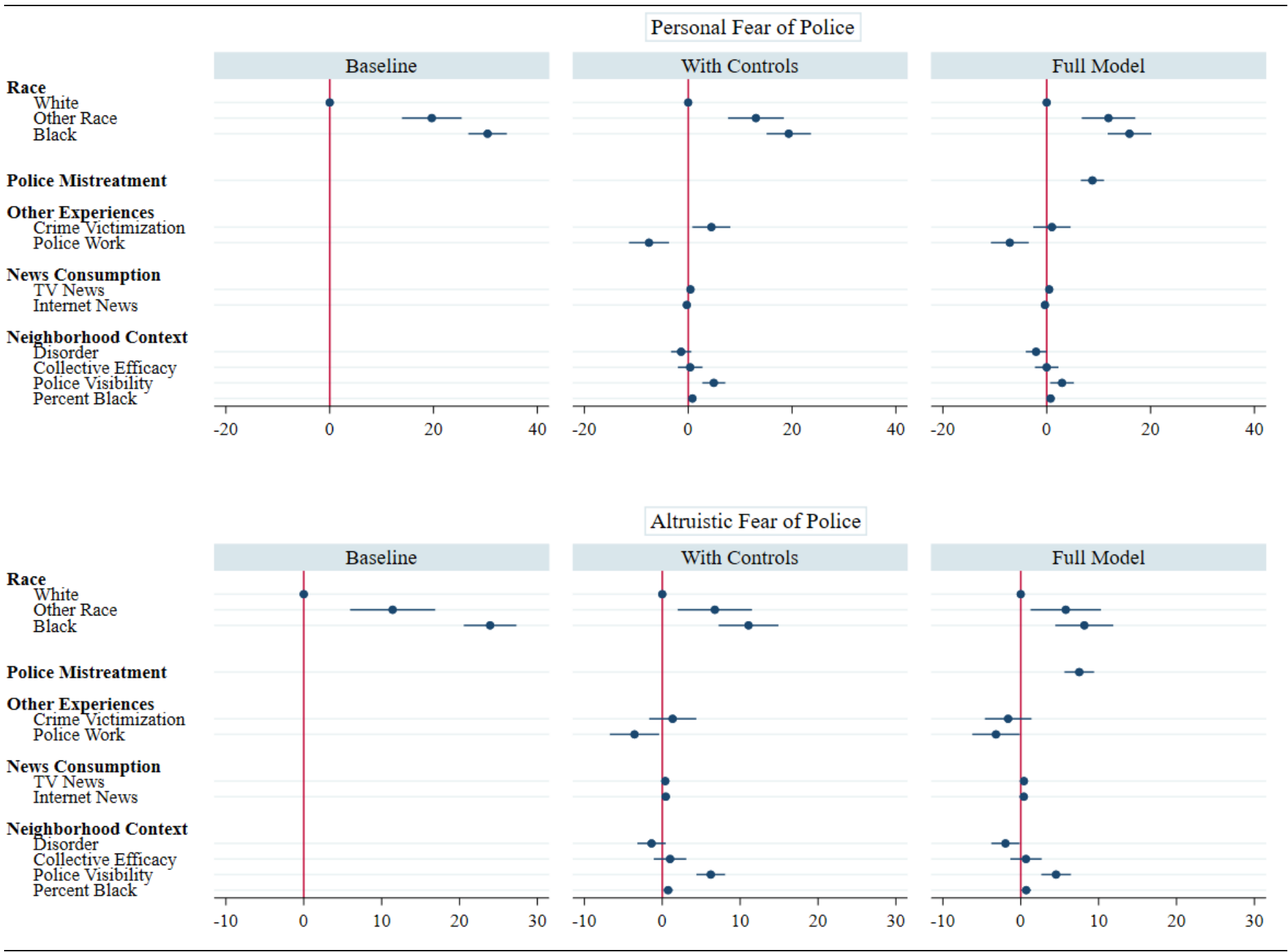

NOTES: The baseline model only controls for gender and age. The other models control for gender, age, education, income, employment status, marital status, parental status, political party and ideology, religious identification, religiosity, fear of crime, urbanicity, and region. Models are estimated with linear regression and robust standard errors. Unstandardized regression coefficients (with 95\% confidence intervals) are shown. The full results are in Tables S4 and S5 of the online supplement. N = 1,149 to 1,150. 


\section{Figure 5. Consequences of Personal and Altruistic Fear of the Police}
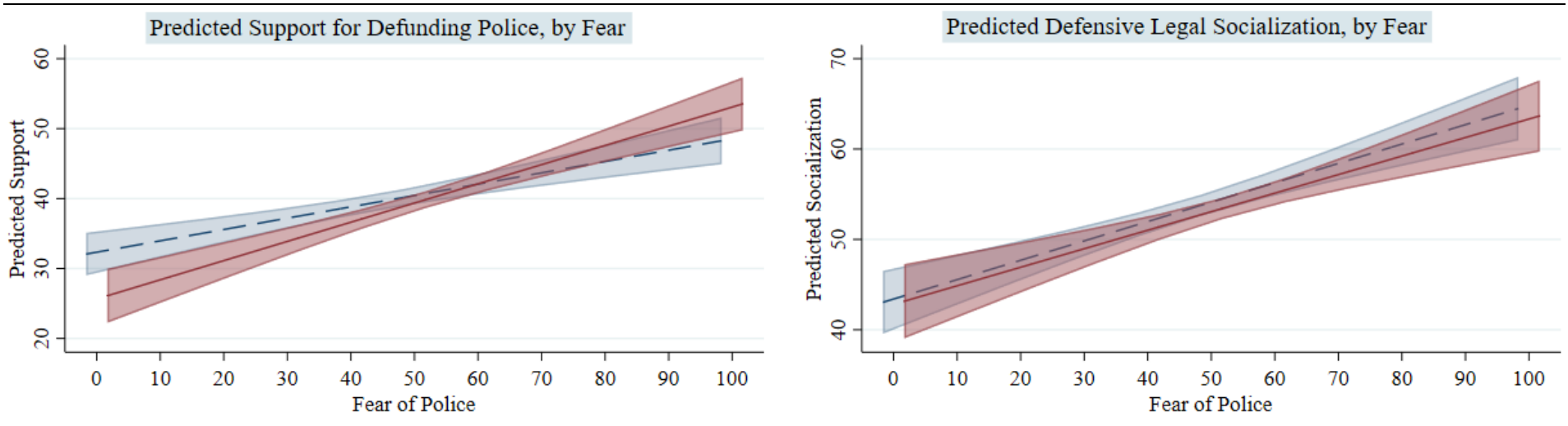

- - Personal $(\mathrm{b}=.162, \mathrm{p}<.001) \quad$ - Altruistic $(\mathrm{b}=.274, \mathrm{p}<.001)$

- - Personal $(\mathrm{b}=.214, \mathrm{p}<.001) \quad$ - Altruistic $(\mathrm{b}=.205, \mathrm{p}<.001)$
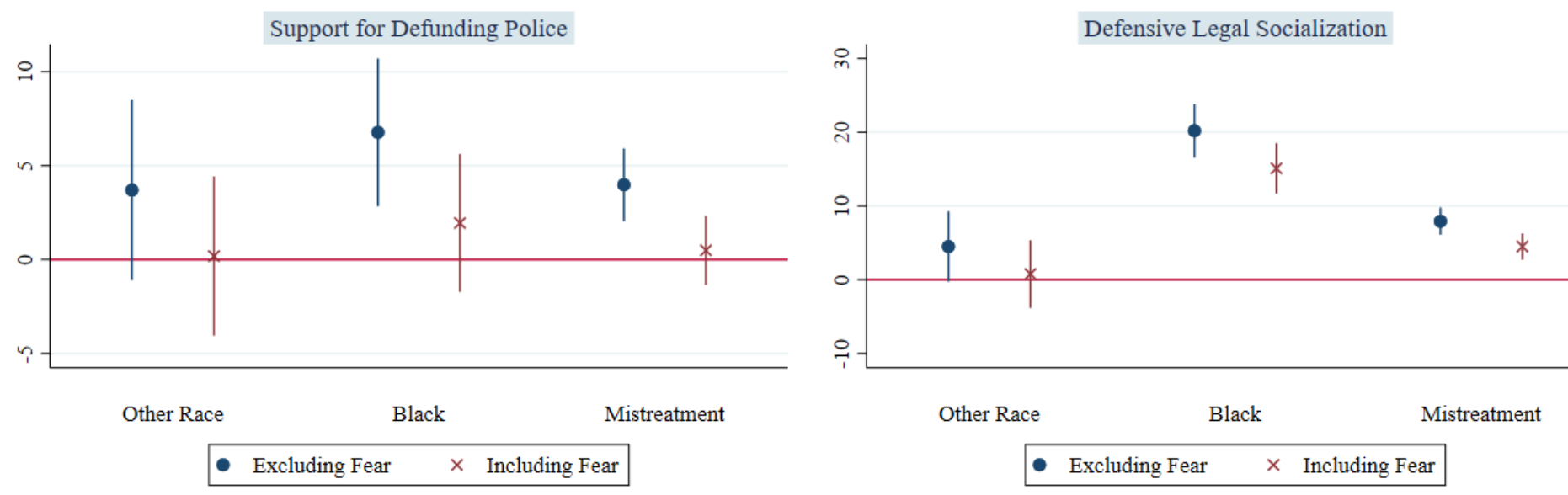

NOTES: The top panels show the unstandardized regression coefficients (for the fear indices, as predictors) and adjusted predictions (at each level of fear) from full models predicting defunding support and defensive socialization, with covariates set to their means. The bottom panels show unstandardized regression coefficients (for race and mistreatment, as predictors) from full models, excluding and including fear. The reference category for race is "White." All models are estimated with linear regression and robust standard errors. The full regression results are in Tables S6 and S7 of the online supplement. $\mathrm{N}=1,149$. 
Figure 6. Would Choose Criminal Victimization Over Police Contact

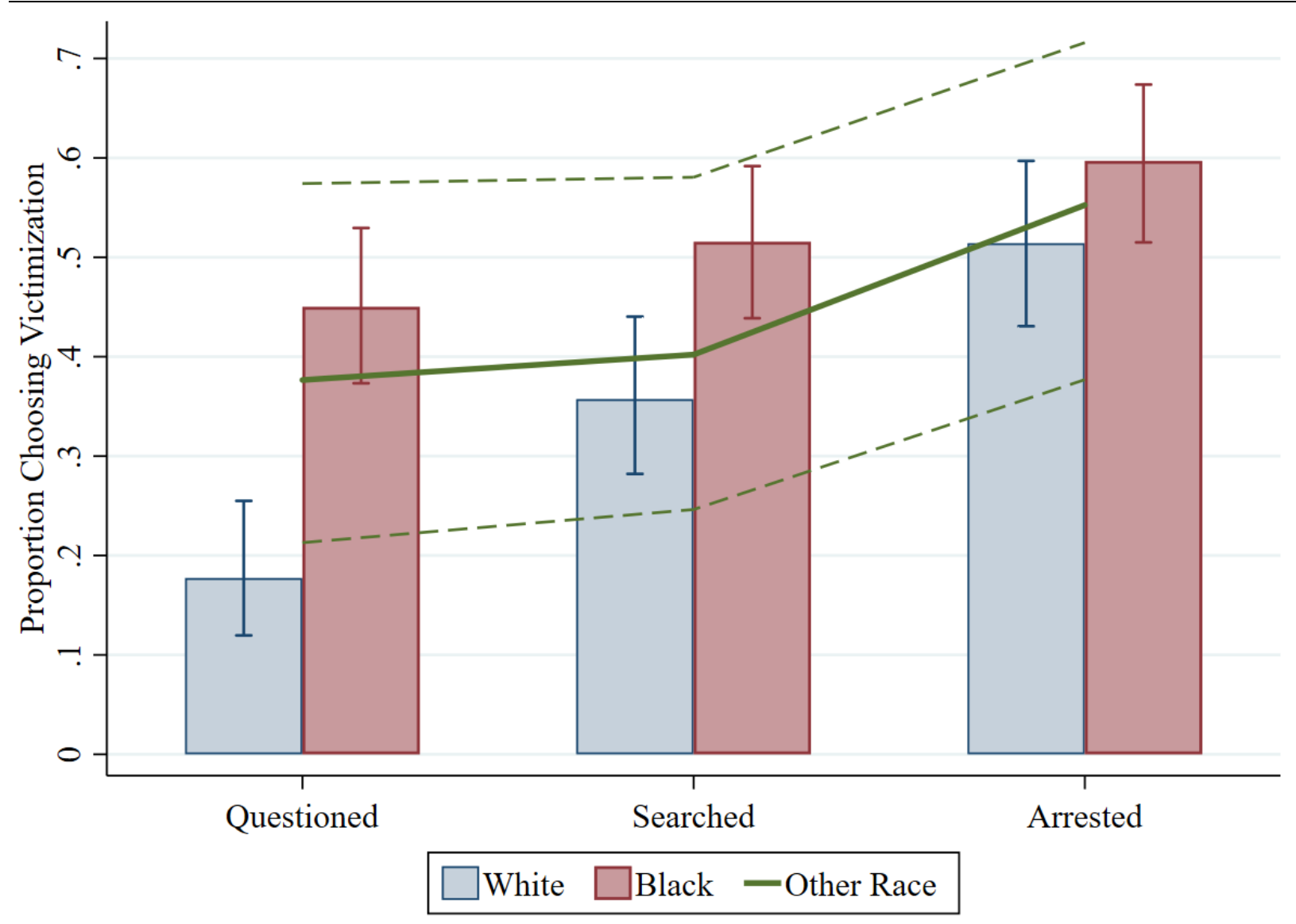

NOTES: This figure shows the proportion of each racial group choosing criminal victimization over specific types of contact with police (with $95 \%$ confidence intervals). $\mathrm{N}=1,148$. 
$\underline{\text { Stem: }}$

Now, we want to ask about EMOTIONAL FEAR. How afraid or unafraid are you that the POLICE will do the following things to you WITHOUT GOOD REASON in the next five years?

Items:

1. Stop you

2. Search you

3. Yell at you

4. Handcuff you

5. Punch or kick you

6. Pin you to the ground

7. Pepper spray you

8. Use a taser on you

9. Shoot at you with a gun

10. Kill you

Response Scale: Very afraid, afraid, neither afraid nor unafraid, unafraid, very unafraid.

Cronbach's $\alpha$ : .980 Factor Loadings: .823 to .958

Notes: We recoded the items so that higher scores indicated greater fear and then averaged them.

\section{Altruistic Fear of the Police}

$\underline{\text { Stem: }}$

How often or rarely do you WORRY about the POLICE hurting the following people?

Items:

1. Your family members

2. Your friends

3. Your neighbors

4. Immigrants

5. Black citizens

6. Hispanic citizens

7. Protesters

Response Scale: Very often, often, sometimes, rarely, very rarely.

Cronbach's $\alpha: .933$ Factor Loadings: .714 to .877

Notes: We recoded the items so that higher scores indicated greater fear and then averaged them. 